\title{
LA CONSTRUCCIÓN IDEOLÓGICA DE LA RESTAURACIÓN EN NUEVA ESPAÑA $(1814-1816)^{*}$ \\ Josep Escrig Rosa \\ Universitat de València
}

INTRODUCCIÓN

G $\mathrm{n}$ 1818, el publicista reaccionario y fraile capuchino Rafael de Vélez aseguró que resultaba "imposible" quitar de las memorias colectivas aquello que había supuesto la experiencia constitucional desarrollada entre la crisis de la Monarquía en 1808 y el regreso de Fernando VII a la península: “ Ojala pudiera borrarse (como dijo nuestro amado soberano) de la historia de los tiempos los años de nuestras reformas [!]". ${ }^{1}$ Esas palabras del rey que el padre Vélez estaba comentando no eran otras que las contenidas en el Decreto que expidió en Valencia

Fecha de recepción: 28 de noviembre de 2018

Fecha de aceptación: 30 de junio de 2019

* HAR2016-78769-P y FPU014/01869. Este trabajo forma parte de una investigación más amplia sobre la contrarrevolución y el antiliberalismo en Nueva España/México entre 1810 y 1824 que se ha enriquecido con comentarios realizados por Encarna García Monerris, Ivana Frasquet y Juan Ortiz. El autor agradece también las pertinentes observaciones de los dictaminadores. Las cursivas dentro de las citas son siempre de los documentos originales.

1 Vélez, Apología del altar y del trono, p. 60. 
el 4 de mayo de 1814, donde, como es sabido, procedió a abolir la obra legislativa de las Cortes de Cádiz y la Constitución que sancionaron en 1812, "como si no hubiesen pasado jamás tales actos, y se quitasen de en medio del tiempo". ${ }^{2}$ A pesar de la lapidaria sentencia, muchas fueron las voces que entonces, a ambos lados del Atlántico, coincidieron con fray Rafael en que la carga de ese pasado inmediato difícilmente iba a desaparecer, tanto por las experiencias y escenarios nuevos que había propiciado como por su capacidad para condicionar el devenir del absolutismo ahora triunfante. ${ }^{3}$

El concepto de Restauración fue acuñado por el polemista suizo Karl-Ludwig von Haller para referirse a la realidad europea posnapoleónica y ha contado con una significativa suerte historiográfica, ${ }^{4}$ a pesar de que los estudios sobre el periodo sean bastante inferiores en comparación con aquellos dedicados al temprano liberalismo. Los trabajos que en el contexto de 2014 han revisado dicho momento histórico insisten en que la vuelta de los monarcas y dinastías expulsados por las revoluciones o el emperador no significó una completa regresión temporal. Más bien al contrario, se abrió entonces un tiempo nuevo difícilmente equiparable con las dinámicas del Antiguo Régimen. Al igual que los liberales de primera hora tuvieron que tener en cuenta cuáles habían sido las líneas de actuación del absolutismo precedente, la contrarrevolución no pudo mantenerse al margen del lenguaje movilizador, universal y utópico de sus enemigos ni

2 El decreto se publicó en la Gaceta Extraordinaria de Madrid, núm. 70 (12 mayo 1814), pp. 515-521.

3 Ibarra, “Cambios en la percepción”, pp. 645-688; Chaparro Silva, “"Todas las cosas tienen su tiempo»”, pp. 206-231 y Gutiérrez y Ossa, “La Restauración”, pp. 10-15.

4 Haller, Restauration; Kissinger, Un mundo restaurado; LA PARra, "La restauración”, pp. 205-222. Una visión panorámica en FRASQUET, "Restauración y revolución”, pp. 29-49. Utilizamos el término Restauración con mayúscula para subrayar que se trata de una etapa específica y definida de la historia que sigue a la revolución liberal en sus primeros momentos. 
obviar los cambios que habían tenido lugar hasta ese momento. Por esta razón, el nuevo poder absoluto se vio obligado a actuar y proyectarse sobre unos marcos de referencia y legitimidad diferentes. ${ }^{5}$ En este sentido, algunos autores han propuesto de manera sugerente que hablar de una "fase de recomposición" da mejor cuenta de las transformaciones que entonces se operaron en escenarios diversos. ${ }^{6}$ Por ello, cuando hablamos de Restauración, lo hacemos considerando que aquello que acontece a partir de 1814 no fue una vuelta al estado de cosas del absolutismo del setecientos. Creemos que las palabras de Pedro Rújula, a quien seguimos de cerca en estas reflexiones, sintetizan perfectamente hasta qué punto el reloj de la historia estuvo entonces lejos de detenerse:

La magnitud de los cambios que habían sufrido la sociedad y la economía, pero también la política y la cultura desde el estallido de la Revolución francesa hasta ese momento eran de tal magnitud que de poco servían ya las viejas fórmulas. Más allá de la voluntad de las antiguas élites para encaramarse de nuevo al poder, basada en la reivindicación de una legitimidad histórica y en la vuelta a patrones políticos y sociales anteriores, la realidad era que había que empezar de nuevo, hacer balance de daños y tratar de recomponer el mundo con los materiales del presente, que no eran, ni mucho menos, los de unos años atrás. ${ }^{7}$

En España, la restitución de Fernando VII al trono, y con él la de algunas de las instituciones del Antiguo Régimen, vino acompañada de la introducción de pautas y acciones de gobierno que alejaban al nuevo régimen fernandino tanto de los parámetros que rigieron antes de 1808 como de lo que estaba

\footnotetext{
${ }^{5}$ García Monerris y Escrig Rosa, “Apologistas y detractores”, pp. 31-72.

${ }^{6}$ Caron y Luis, "Le temps des Restaurations", pp. 461-466, esp. p. 462.

7 Rújula, "Recomponer el mundo", pp. 11-15, la cita en pp. 11 y 12.
} 
sucediendo en otros países de Europa. ${ }^{8}$ Los contrarrevolucionarios de la península trataron de presentar los acontecimientos que tuvieron lugar en 1814 como una vuelta al orden natural que la revolución había trastocado. Puede hablarse de un proyecto político e intelectual que se encaminó a recuperar el poder y superar un pasado inmediato que se advertía anómalo dentro de la historia de la Monarquía. 9 Pero si grande fue el impacto del liberalismo en la península, no lo fue menor en sus territorios ultramarinos, donde, además, desde muy pronto empezaron a surgir propuestas que desafiaron ese control. ${ }^{10}$ Tampoco allí pudo procederse a una completa vuelta atrás cuando llegaron las noticias del regreso de "El Deseado". Los cambios habían sido de tal calibre que los diversos actores fueron conscientes del difícil escenario que entonces se les presentaba. Para Nueva España, que es el espacio en el que nos interesa situarnos, Tomás Pérez Vejo ha señalado tres factores que dificultaron el retorno del absolutismo y obligaron a las autoridades a redefinir sus posiciones y actitudes: el impacto y arraigo del proceso gaditano, en especial mediante la creación de nuevos ayuntamientos y diputaciones provinciales; el desprestigio de la figura del virrey desde la destitución de José de Iturrigaray en 1808, y la incapacidad de las tropas realistas para reducir a los insurgentes dispersos en

${ }^{8}$ De acuerdo con Emilio La Parra, en términos generales la palabra "restauración" se refiere "a la hegemonía alcanzada por el pensamiento reaccionario tras la revolución, pero también a la creación de un nuevo orden caracterizado por la transacción entre procesos culturales precedentes y sucesivos". Ello resulta difícil de aplicar para lo acontecido en la península porque, según señala acertadamente dicho historiador, "el pensamiento y las actitudes reaccionarias alcanzaron en España tal hegemonía, que eliminaron de la esfera pública cualquier alternativa". Por tanto, "no hubo sustitución de una Constitución por otra, ni reconocimiento de los derechos ciudadanos, y no se registró ningún intento de transacción política, sino todo lo contrario". LA PARRA, "La Restauración”, pp. 206 y 207.

9 Luis, "La construcción inacabada", pp. 319-346; y Rújula, "El mito contrarrevolucionario", pp. 79-97.

10 BreÑa, El primer liberalismo; y ChUST y Frasquet, Tiempos de revolución. 
guerrillas. ${ }^{11}$ La gestión del cambio de régimen recayó sobre Félix María Calleja, quien, como ha señalado Juan Ortiz, aprovechó el contexto para impulsar una Restauración novedosa basada en la primacía de lo castrense y un reforzamiento de su autoridad sin parangón hasta el momento. ${ }^{12}$ Los conflictos con las principales fuerzas del virreinato no se hicieron esperar y acabaron llevando a su propia destitución en septiembre de 1816. A partir de este momento lo sustituiría Juan Ruiz de Apodaca, el cual iba a continuar el proyecto de pacificación de su antecesor, aunque desde enero de 1817 impulsó una política de concordia por medio de nuevas ofertas de indulto a los sublevados. ${ }^{13}$

De una manera similar a lo sucedido en España, el periodo del sexenio absolutista no ha despertado tampoco en México gran interés hasta fechas bastante recientes. Para aquellos interesados en el liberalismo se trataba de una interrupción, de un lastre coyuntural al inevitable proceso de cambio abierto en 1808 y que acabaría llevando al triunfo de la República. De la misma forma, para los estudiosos de la insurgencia pareció que los años de desorganización y supuesta victoria realista que siguieron a la muerte de José María Morelos no tenían demasiado interés. El momento, sin embargo, ha acabado desvelándose como una etapa fundamental en la construcción del Estado-nación, tal y como ha señalado José Antonio Serrano. Se trata de un periodo desde donde debe rastrearse el origen de muchas de las tensiones que aflorarán con la independencia, la asunción de algunas medidas puestas en marcha por el reformismo ilustrado y la legislación emanada de las Cortes de Cádiz, así como la reorientación de las estrategias en el campo de los sublevados. ${ }^{14}$

11 Pérez Vejo, “Una Restauración que no restaura”, pp. 163-182, esp. p. 171.

12 Ortiz, Calleja.

13 Moreno, “La Restauración”, pp. 101-125, esp. pp. 119 y 120.

${ }^{14}$ Serrano (coord.), El sexenio absolutista. También incide sobre la importancia del periodo Zermeño, "El retorno de los jesuitas", pp. 1463-1540. De una manera más general, constata la menor atención prestada al estudio de la 
Otra muestra del grado de complejidad que alberga esta etapa lo encontramos en el ámbito conceptual. Para el caso novohispano, debajo del término realista -como se sabe, el más comúnmente utilizado por parte de la historiografía para referirse a aquellos que se opusieron a la insurgencia y, a partir del golpe contrarrevolucionario de mayo de 1814, al amplio proceso que se derivó de la reunión de las Cortes de Cádiz- encontramos grupos o filiaciones ideológicas heterogéneas difíciles de identificar. ${ }^{15}$

Conscientes del trabajo que todavía queda por hacer, el siguiente estudio busca complejizar el periodo mediante el análisis de los componentes teóricos e ideológicos que sirvieron para legitimar la Restauración en Nueva España, en especial entre los años 1814 y 1816, aunque necesariamente se referirán algunas publicaciones posteriores. Se parte de la premisa de que el problema debe ser abordado desde tres facetas interconectadas. En primer lugar, resulta preciso atender a las distintas bases doctrinales sobre las que se proyectó el golpe de Estado de 1814 y cuál fue la interpretación de las mismas que se realizó al otro lado del Atlántico. Lejos de encontrarnos con un acatamiento

contrarrevolución en el periodo de la independencia Ávila, "Cuando se canonizó la rebelión”, pp. 43-85. La bibliografía sobre la insurgencia es extensa; remitimos a los siguientes trabajos y las obras en ellos referidas: GuZMÁN PÉrez, "Repensar la insurgencia novohispana”, pp. 339-358; OrTIZ, Guerra y gobierno, y Herrejón, Morelos. Concretamente, para el periodo que nos ocupa pueden verse Mejía, "La transición”, pp. 331-374 y SAUCEdo, "La convención”, pp. 375-396.

15 Como señala Moreno, "Los realistas", pp. 1077-1122, esp. pp. 1091 y 1092, estamos ante un concepto que, en el momento al que nos referimos, fue utilizado en una doble dirección. Por un lado, en los textos insurgentes aparece para mencionar a los partidarios del gobierno virreinal. Por otro, en la documentación oficial se utiliza a la hora de designar a un tipo específico de milicias. Sin embargo, a pesar de referirse en esta segunda acepción a las fuerzas armadas, lo cierto es que por "cuestiones prácticas" se ha empleado dicho término de manera más general "para poder explicar a los principales grupos y bandos que intervinieron en el proceso", lo cual no contribuye a la compresión del mismo, tal y como señala Rodríguez TAPIA, "Los opositores”, p. 15. 
completo de los mandatos emanados desde la península, la máxima autoridad del virreinato no solo expresó su opinión sobre los acontecimientos, sino que aprovechó el contexto para negociar una situación que resultara favorable a sus intereses. Las fuentes utilizadas para el caso del virrey Calleja nos ilustran suficientemente sobre aquello que queremos demostrar en este apartado. La correspondencia que mantuvo con el ministro de Gracia y Justicia, así como los documentos relativos a lo acontecido en la península, nos permiten captar lo que fue su interpretación de la situación política que atravesaba la Monarquía. En cualquier caso, se trató por parte de Calleja de asegurar su permanencia en el poder, consciente de la inestabilidad y de las ambigüedades del momento. Sobre la base de estos materiales podrá observarse un doble proceso en la construcción del mito del retorno al orden perdido.

En segundo lugar, se analizan los elementos teóricos que sirvieron para sustentar dicho constructo. Si la vuelta del monarca fue justificada por medio de diversas fuentes de legitimidad, en el ámbito religioso la superación de la crisis se cifró en la reinstauración de la Inquisición, el retorno de los jesuitas, la expansión de las misiones y la liberación de Pío VII. Los documentos utilizados para el análisis e interpretación de esta parte son unos materiales privilegiados en la medida en que, por medio de ellos, podemos conocer el modo en que los contrarrevolucionarios construyeron su discurso. En este punto hemos de tener en cuenta que la mayor parte de los textos seleccionados fueron obra de eclesiásticos. Su lenguaje necesariamente nos va a remitir constantemente al mundo de la religión, a planteamientos maniqueos de la realidad y a una cosmovisión del mundo en la que, sin abandonar la fuerza de la Providencia, la acción de los individuos ocupa un lugar destacado. Se busca ante todo atraer la atención de la comunidad sobre la bondad y certeza de sus palabras. Son escritos pensados para convencer y para la acción. Los receptores de los sermones, opúsculos o 
pastorales necesitan de la mediación de estos religiosos para hacer inteligible una realidad que se advertía en continuo cambio. Por ello los referentes bíblicos constituían una cantera de ejemplos con los que fácilmente se podían establecer analogías. Estamos, no obstante, ante unas fuentes que deben examinarse prudentemente, sin perder de vista el contexto en el que se producen, su capacidad de incidir sobre las prácticas políticas y la intencionalidad que albergan. Aquello, en suma, que muestra esta publicística es el modo en que percibían la realidad sus autores y cómo pretendían intervenir en ella. Como han puesto de relieve Carlos Herrejón y Brian Connaughton, la conversión de la mayoría de estos discursos en folletos impresos les iba a dar una enorme difusión y perdurabilidad. ${ }^{16}$

Por último, a pesar de estos argumentos retóricos, los documentos dan cuenta de que, para los actores, el periodo de desórdenes se resistía a cerrarse, aspecto distinto del ambiente que se respiraba en la península. Aunque con una capacidad operativa en regresión, el conflicto con los insurgentes seguía vivo y esto dificultaba completar el ciclo reparador. Resultaba imposible alcanzarlo si la guerra continuaba y los insurrectos persistían en sus planes, ahora ya con una clara intención independentista. En el fondo, los realistas novohispanos interpretaron que la insurgencia era una continuación de los planes tramados por los falsos filósofos europeos contra el Altar y el Trono. Esta cuestión resulta importante porque permite conectar el debate mantenido por los contrarrevolucionarios de ambas orillas del Atlántico, dando cuenta de su trascendencia en la construcción de un estado de opinión capaz de rebatir ingeniosamente a sus enemigos. Poner fin al conflicto devino, por tanto, una prioridad. En esta síntesis compleja y tensa entre una Restauración

${ }^{16}$ Herrejón, Del sermón al discurso cívico, y Connaughton, Entre la voz de Dios, pp. 84-96. Un ejemplo ilustrativo sobre el particular en Campos, "Del absolutismo regio", pp. 107-158, esp. pp. 127-144. 
que se percibía completada y otra que se entendía pendiente y basada en la lucha activa consideramos que reside la originalidad del problema planteado en Nueva España. El resultado fueron fórmulas inéditas de disputa política y de movilización que nos revelan el desafío que supusieron las alternativas formuladas por las Cortes de Cádiz y la insurgencia, pero también las visiones contrapuestas dentro del mismo absolutismo. Se trató de un reto en el que los individuos se vieron obligados a resituarse si querían evitar la pérdida de su protagonismo.

En conjunto, el análisis de un elenco de autores y de fuentes diversas -que no se agotan en las aquí seleccionadas-nos permitirá rastrear las coordenadas simbólicas con las que se construyó aquello que acabará deviniendo en una utopía restauradora. Cada uno de los aspectos seleccionados podría constituir un estudio autónomo por sí mismo, pero, por cuestiones de espacio, en esta ocasión se presenta una visión general del fenómeno. Estamos ante un proyecto que debe ser analizado en plural y desde el horizonte discursivo de los propios sujetos a la hora de valorar su capacidad para conformar una alternativa política y cultural a la revolución en un escenario que poco tenía que ver con el de 1808. De hecho, tampoco puede decirse que ese momento les convenciera a la hora de buscar en el pasado modelos de conducta que sustentaran las acciones del presente. Ante un ayer con el que no se sentían cómodos, los actores lanzaron sus miradas sobre un tiempo pretérito y lejano que se prestaba a lecturas mucho más dúctiles. Tanto los liberales como sus detractores fueron sabedores de que el recurso a la historia era necesario para poder pensarse políticamente. Ello debería servirnos para poner en cuestión ciertas interpretaciones que han imputado escasa capacidad de raciocinio e innovación a las propuestas de los contrarrevolucionarios, generalmente relegadas a un segundo plano en las investigaciones del periodo. Además, siguiendo las estrategias anteriores, los realistas no dudaron en utilizar su apoyo a la corona para introducir demandas que dieran salida 
a viejas reivindicaciones criollas. ${ }^{17}$ Aunque se tratara de suturar la brecha, lo cierto es que el "horizonte de expectativa" cada vez se encontraba más alejado del "campo de experiencia". ${ }^{18}$ La independencia en septiembre de 1821 vendría a confirmarlo para muchos.

\section{EL ASALTO AL PODER Y LAS LÍNEAS DE FRACTURA DEL ABSOLUTISMO}

Tras la firma del Tratado de Valençay el 11 de diciembre de 1813, Napoleón Bonaparte reconoció como monarca de España a Fernando VII y se puso fin a su cautiverio iniciado tras las abdicaciones de Bayona. Las Cortes habían previsto la hoja de ruta que seguiría cuando entrara en la península, debiendo dirigirse sin demora hacia Madrid para jurar la Constitución. ${ }^{19}$ Sin embargo, el hijo de Carlos IV emprendió entonces una "política misteriosa”, tal y como la definió El Conciso, ${ }^{20}$ que lo llevó hacia el este, concretamente a Valencia, donde lo esperaba el capitán general Francisco Javier Elío. El militar y su tropa no tardaron en expresarle su firme voluntad de devolverle al trono de sus antepasados "en la plenitud de los derechos que os concedió la naturaleza”. ${ }^{21}$

En dicha ciudad se le entregó al rey una Representación y Manifiesto que habían elaborado 69 diputados de las Cortes. El conocido como "Manifiesto de los Persas" deslegitimaba la opera magna gaditana y planteaba al monarca una particular hoja de ruta alternativa a la propuesta por el liberalismo. ${ }^{22} \mathrm{La}$

\footnotetext{
17 Serrano, “El discurso de la unión”, pp. 157-177.

18 Koselleck, Futuro pasado, pp. 333-357.

19 La Parra, Fernando VII, pp. 224-276.

20 Citado por Butrón, “Redefinir rey y soberanía”, pp. 59-78.

21 Citado por García Monerris y García Monerris, La nación secuestrada, p. 27.

22 Representación y Manifiesto.
} 
gestación del documento hay que buscarla en las nuevas tácticas electorales que los serviles hicieron valer en el contexto de la convocatoria de elecciones para las Cortes ordinarias. Muy pronto fueron conscientes de que el Parlamento debía ser ocupado, tanto para evitar una profundización en los aspectos revolucionarios del liberalismo como para hacer viable -llegado el momento- su desarticulación desde dentro. ${ }^{23}$ Por tanto, la Representación y Manifiesto surgió desde la Cámara y sus firmantes se presentaron como los "legítimos representantes de la Nación" frente a los diputados liberales, a los cuales anatemizaron por tratar de establecer un "gobierno democrático". Es decir, en su declaración en ningún momento renunciaron a su carácter de procuradores, pues se mostraban en todo dispuestos a recuperar la "antigua Constitución Española” en las Cortes estamentales que pedían a Fernando VII reunir. Al mismo tiempo, aseguraban aborrecer el despotismo y calificaban a la monarquía absoluta como "obra de la razón y de la inteligencia", además de "subordinada a la ley divina, a la justicia y a las reglas fundamentales del Estado".

Semejante exposición de principios doctrinales ha servido para que el texto de los "Persas" haya sido objeto de diversas interpretaciones. Ya en su momento el Conde de Toreno comentó en su Historia del levantamiento, guerra y revolución de España (1835-1837) que hablar de monarquía absoluta y pretender la convocatoria de Cortes al estilo tradicional era una "contradicción manifiesta, pero común a los que se extravían y procuran encubrir sus yerros bajo apariencias falaces". ${ }^{24}$ En el siglo xx, mientras que para unos constituyó la máxima expresión doctrinal del realismo "reformador", 25 otros lo consideraron como "el conjunto de tópicos políticos elaborados por los reaccionarios

${ }^{23}$ Rújula, "Reacción en las Cortes de Cádiz”, pp. 257-278.

${ }^{24}$ Citado por Rivera, Reacción y revolución, p. 253.

25 SuÁrez Verdeguer, Conservadores, innovadores y renovadores, y DizLois, El manifiesto de 1814. 
de Cádiz", ${ }^{26}$ y hay quien incluso vio en él un cierto espíritu "liberal". ${ }^{27}$ Sin embargo, hoy parece más acertado interpretar el documento dentro de las propuestas pactistas de tipo antiliberal-pero no reaccionarias- que entonces se formularon para afrontar la crisis de la Monarquía. ${ }^{28}$ En este sentido, para Javier López Alós aquello que los "Persas" estaban concretando en su escrito podría considerarse en términos de un "falso absolutismo católico" o "absolutismo sui generis", en el que el monarca, a pesar de concentrar el poder ejecutivo, estaría sujeto a todo un elenco de leyes históricas y etéreas que limitarían su autoridad. $\mathrm{Al}$ respecto nos aclara lo siguiente: "se trata de un absolutismo que contradice el principio de princeps legibus solutus est: no puede crear un Estado ni disponer mecánicamente las normas de su mantenimiento". ${ }^{29}$

En correspondencia a lo solicitado por los "Persas", Fernando VII emitió el decreto de 4 de mayo, en el que procedió a derribar el régimen liberal. Además, se comprometía a llevar adelante algunas medidas de talante reformista, tales como una convocatoria de Cortes estamentales, respeto a la libertad y seguridad individual, imprenta moderada, racionalización administrativa y acatamiento de las leyes fundamentales que fueran revisadas por la Asamblea. Una vez más se insistía en el alejamiento de cualquier tentativa autoritaria: "Por manera que estas bases pueden servir de seguro anuncio de mis Reales intenciones en el gobierno de que Me voy a encargar, y harán conocer a todos no un Déspota ni un tirano, sino un Rey y un

\footnotetext{
${ }^{26}$ Herrero, Los orígenes, p. 339.

27 Murillo Ferrol, “El «Manifiesto de los Persas»”, pp. 164-165.

28 Ávila, "Cuando se canonizó la rebelión”, pp. 62 y 63; Escrig Rosa, "Los «príncipes del siglo»", pp. 139-159, y Calvo, "La Constitución de la monarquía”, pp. 165-192. También BREÑA, El primer liberalismo, donde comenta que el documento, pese a sus "limitaciones programáticas", "sí pretendía cambiar el modo en que había funcionado la monarquía durante décadas", p. 243. ${ }^{29}$ López Alós, Entre el trono y el escaño, pp. 208-210.
} 
padre de sus vasallos". Aparentemente el monarca entraba en la senda de la moderación que también había anunciado en Francia Luis XVIII con su Declaración de Saint-Ouen y la futura Carta Otorgada en la que se sancionaron ciertos logros de la revolución. Sin embargo, muy pronto se puso de relieve que Fernando VII no estaba dispuesto a ser consecuente con aquello que había anunciado. ${ }^{30}$

Bajo su gobierno se implantó aquello que las profesoras García Monerris han definido como un "absolutismo postrevolucionario de nuevo cuño" de carácter patrimonialista y basado en la concentración del poder en sus manos sin límites ni intermediarios. ${ }^{31}$ La plena capacidad soberana que los revolucionarios depositaron en la nación fue admitida por Fernando VII sin ningún tipo de cortapisas, rompiendo, por tanto, con los límites que solicitaban los "Persas", con quienes no había contraído ningún tipo de compromiso formal. La represión cayó sobre los liberales ${ }^{32}$ y el monarca se lanzó a una operación sin precedentes para recuperar los bienes y rentas del Real Patrimonio, ahora privatizado. Una parte de la nobleza que había apoyado el golpe de Estado pronto mostraría su malestar con un rey que nunca les devolvió las jurisdicciones señoriales que las Cortes de Cádiz les arrebataron en agosto de $1811 .{ }^{33}$ Semejante actitud mostró respecto al otro de sus puntales, la Iglesia. Esta contribuyó a crear la imagen de un rey predestinado esperando recibir un trato privilegiado cuando se completara la operación. ${ }^{34}$ No obstante, conforme el monarca se fue sintiendo seguro en el trono

30 La Parra, Fernando VII, pp. 279-374.

31 García Monerris y García Monerris, “El rey depredador”, pp. 21-47.

32 Cantos y Ramos, La represión absolutista; Roca, "La Restauración de Fernando VII", pp. 5-28 y Frasquet, "En defensa de la Constitución”, pp. 213-238.

33 García Monerris y García Monerris, Las cosas del rey, pp. 51-63.

${ }^{34}$ Moliner Prada, "El antiliberalismo eclesiástico", pp. 51-72 y La Parra, "Fernando VII", pp. 39-53. 
retomó la vía regalista que tanto aborrecían los ultramontanos y que iba a causar no pocos enfrentamientos. ${ }^{35}$

Vistas las tensiones iniciales, cabe preguntarse a continuación cómo fueron recibidas las noticias sobre el golpe de Estado en Nueva España. El 11 de agosto de 1814 se insertaba en la Gaceta del Gobierno de México un aviso del día anterior. En él se comunicaba que el virrey Félix María Calleja había recibido "en copia manuscrita” un decreto del rey dado en Valencia. Se aseguraba que este no había sido insertado por el momento al estar la copia "llena de incorrecciones, defectos de pluma y ortografía, y falta de palabras". ${ }^{36}$ No sabemos qué reacciones y expectación generó un mensaje tan enigmático, pero lo cierto es que dos días más tarde se dio a conocer su contenido "por no defraudar a este fidelísimo público” y a la espera de publicar "el primer ejemplar que llegue íntegro". ${ }^{37}$ Pero Calleja no se contentó solo con anunciar el retorno del absolutismo en el conjunto de la Monarquía. Inmediatamente vio la posibilidad de utilizar a su favor las incertidumbres que generaba el disloque entre la emisión de las nuevas órdenes y su llegada a ultramar. Sin duda alguna no desaprovechó la posibilidad de ampliar su campo de acción. A los pocos días hizo publicitar un bando en el que realizaba una lectura bastante particular del decreto del 4 de mayo. Atendiendo al tenor de lo expresado por el monarca, el virrey anunciaba que no iba a proceder a la supresión inmediata de las instituciones gaditanas. Aseguraba que por el momento era preciso no entorpecer "el curso de los negocios en la administración política, gubernativa y de justicia en estos dominios”, de manera que debía "subsistir todo por ahora en el ser y estado

35 Rodríguez López-Brea, “¿Alianza entre trono y altar?”, pp. 29-46; y Artola, "La alianza imposible”, pp. 155-184.

36 Gaceta del Gobierno de México, núm. 612 (11 ago. 1814), p. 883.

37 Gaceta del Gobierno de México, núm. 613 (13 ago. 1814), p. 891. El propio Alamán, Historia de México, p. 118, aseguró que Calleja publicó una copia del decreto "imperfecta y trunca”. 
en que se halla". Solo cuando se recibieran nuevas disposiciones dictaría "las providencias oportunas para su cumplimiento". ${ }^{38}$ Esta particular interpretación no iba a estar exenta de conflictos. Los oidores de la Real Audiencia, por ejemplo, reclamaron prestamente recuperar unos fueros que Calleja se resistía a devolverles. ${ }^{39}$ Las críticas al liberalismo que inmediatamente formuló no fueron óbices para que utilizara a su favor aquellos resortes políticos con los que podía reforzar su autoridad.

Pero el documento más importante para conocer cuál era su posición ante este contexto inédito fue la extensa carta que dirigió al ministro de Gracia y Justicia el 18 de agosto. En ella se propuso exponerle a Fernando VII una radiografía de la situación en que se encontraba Nueva España, justificar cuál había sido su conducta política hasta el momento y cómo pensaba que se debía actuar a partir de entonces. ${ }^{40} \mathrm{El}$ documento es conocido, pero resulta imprescindible detenernos en él brevemente por las razones que inmediatamente comprobará el lector. Calleja situaba el punto de partida de los trastornos en las Cortes de Cádiz y la Constitución que sancionaron. Con anterioridad ya se había referido a los diputados que allí se congregaron, entre los que decía reinar "una especie de francmasonería”, pues "todos están unidos, caminan [a] un fin, obran por iguales principios, y no se descubren jamás". ${ }^{41}$ Sus planes para acabar con el Trono, el Altar y el dominio español sobre sus territorios ultramarinos no conocían fronteras, de manera que era fácilmente perceptible que los parlamentarios y los insurgentes formaban parte de una misma conspiración de carácter universal. El "politiquismo" era el

38 “Bando" de Félix María Calleja (17 ago. 1814) inserto en la Gaceta del Gobierno de México, núm. 615 (18 ago. 1814), p. 915.

39 Serrano, "Las herencias ilustradas", pp. 191-227.

40 Félix María Calleja al ministro de Gracia y Justicia, México (18 ago. 1814); AGI, México, 1676.

${ }^{41}$ Félix María Calleja al ministro de Gracia y Justicia, México (30 jul. 1814); AGI, México, 1845. 
verdadero mal del nuevo siglo. Todas las clases sociales se habían infectado, "sacando de su esfera al comerciante, al artesano, al eclesiástico y al labrador”. Los graves síntomas de un completo aturdimiento ponían de relieve que la confusión era absolutamente general. ${ }^{42}$ Ante este panorama el virrey aseguraba haberse encontrado indefenso. Las armas no servían exclusivamente para enfrentar un nuevo tipo de rebelión en el que la imprenta y la opinión habían pasado a ocupar un lugar preponderante: "la guerra más temible y peligrosa no la hacen las gavillas armadas, sino los malvados e hipócritas contra quienes no tengo armas con tantas restricciones y grillos”, aseguraba. ${ }^{43}$

En aras de un interés superior como lo era el de la patria, decidió sobrepasar los límites que le imponía la legislación gaditana: suprimió la libertad de imprenta, designó jueces de letras, mantuvo el Juzgado de Policía y se dotó de poderes superiores en el conjunto del territorio, subordinando todas las Diputaciones provinciales y jefes políticos a su mando. En ningún caso estaba dispuesto a tolerar que la autoridad del virrey se desprestigiara, a pesar de que la Constitución hubiera abolido dicha figura. Resultaba intolerable que algunos consideraran que esta "no era otra cosa que un mero Capitán General de Provincia”. El retorno del rey resultaba el momento propicio para poner coto a los altercados. Pero la situación en Nueva España resultaba más compleja que en la península, pues la guerra civil inaugurada en 1810 por el cura Miguel Hidalgo continuaba aumentando el número de bajas. A pesar del protagonismo que desempeñó el ejército en la restitución al trono del rey, ${ }^{44}$ parece que en la península las armas no ocuparon el lugar preponderante que

\footnotetext{
${ }^{42}$ Félix María Calleja al ministro de Gracia y Justicia, México (18 ago. 1814), AGI, México, 1676.

${ }^{43}$ Félix María Calleja al ministro de Gracia y Justicia, México (30 jul. 1814), AGI, México, 1845. Sobre la eclosión de lo público véase Guerra, Modernidad e independencias.

${ }^{44}$ García Monerris y García Monerris, La nación secuestrada, pp. 26-30.
} 
podría esperarse en el conjunto del discurso legitimador de la Restauración. ${ }^{45}$ Sin embargo, para Calleja resultaban decisivas. El conflicto bélico era el centro de su discurso, tal y como lo atestiguan las siguientes palabras: "la continuidad de la guerra en todos aspectos es el mayor de los males que podemos experimentar, y el que seguramente nos conduce a una infalible ruina trascendental a la península”. El colapso se presentaba inminente. Evitarlo requería de acciones contundentes. Solo si se aumentaba su capacidad de mando transitoriamente se podría derrotar a los sediciosos. "En tal situación -decía-, no queda más recurso que el reanimar la autoridad y hacer un esfuerzo para que la guerra concluya, descargando un golpe decisivo sobre la rebelión." Concebía esta etapa como un paréntesis de excepción urgente y previo a la estabilización del tiempo histórico. Proceder a una vuelta atrás sin dicha depuración era una quimera. $\mathrm{Al}$ igual que lo observó el padre Vélez, para el virrey los acontecimientos recientes habían quedado marcados con tinta indeleble, condicionando decisivamente el rumbo político que cabía seguir ahora:

No basta ya la reposición de las antiguas leyes: ellas pudieron en algún tiempo mantener en estos pueblos una justa ilusión hacia la potestad de los Jefes y Magistrados y un grande respeto a sus disposiciones y providencias; pero abatidas ya, desacreditadas y puestas en ridículo por el nuevo sistema, tachadas de injustas y arbitrarias, atribuidas a un origen ilegítimo y expuestas al ludibrio universal, han perdido su antigua influencia y representación, y no son ya capaces de imponer a un pueblo desenfrenado que se ha atrevido a familiarizarse con su escarnio, y que ha roto los diques de la obediencia.

La explosión del volcán social impelía a la aplicación de nuevas medidas. Las ordenanzas antiguas no bastaban para

$\overline{45}$ RÚJula, “El mito contrarrevolucionario”, p. 91. 
contener el efluvio de un pueblo desbocado y entregado a sus propias pasiones. Estas leyes fundamentales, además, habían sido desprestigiadas por los políticos modernos, quienes no tuvieron problemas en alterarlas a su capricho. Era evidente que el principio de autoridad se hallaba socavado, resultando imposible imponerse por los medios tradicionales. La vuelta atrás anunciada por el monarca debía esperar. La propuesta de Calleja era contundente: hacía falta un "proceder enérgico" y una "fuerza respetable" que pasaba por implantar la "ley marcial” hasta domeñar a los insurrectos. Se trataba de un "heroico remedio" que precisaba del apoyo de la fuerza armada, para lo cual solicitaba que se enviaran entre 6 y 8000 soldados, aunque con estos tampoco se concluiría la obra. Si era preciso él mismo se colocaría una vez más al frente de las tropas para "llevar a sangre y fuego el país hasta aniquilar los infames y clavar donde quiera el Pabellón del Monarca de España”. Solo después de este “impulso más activo y eficaz” podrían "entrar de nuevo a ejercer su imperio los antiguos códigos” o, añadía, "lo que S. M. dispusiere para la dirección de sus dominios en estado pacífico y sumiso". ${ }^{46}$

Lo realmente interesante de estas consideraciones era la perspectiva desde la que Calleja estaba proyectando sus planes. Aunque no lo mencionara, toda la exposición era un comentario crítico al espíritu de moderación del decreto del 4 de mayo que acababa de conocer. De las consideraciones descritas se desprende que el virrey discrepaba de las directrices conciliadoras que Fernando VII, al menos teóricamente, estaba marcando para el gobierno de la Monarquía. Estas no eran aplicables para los territorios de ultramar. ${ }^{47}$ En este punto cabe señalar que en el conjunto del documento Calleja parecía hacer extensibles sus

46 Félix María Calleja al ministro de Gracia y Justicia, México (18 ago. 1814), AGI, México, 1676.

47 De hecho, estas políticas represivas iban a ser criticadas desde la península, tal y como señaló FARris, La corona y el clero, pp. 207-211. 
orientaciones a todos los territorios americanos que se encontraban en guerra. Si el complot de los sofistas e insurrectos era universal, la respuesta no podía reducirse a un ámbito concreto. Desde luego, en este punto sus opiniones parecían coincidir con las del virrey peruano Fernando de Abascal (1806-1816), quien consideraba que se estaban esparciendo "los principios revolucionarios de la democracia [...] sin que las nuevas autoridades que por ella se establecen pudieran reprimirlos”. Los dos militares insistían en que su presencia en América había sido un garante para que dichos territorios no se perdieran, aunque se precisaba una mayor capacidad resolutiva para mantenerlos. Cuando fue destituido, Abascal aseguró que guardaba en su memoria "la gloria de haber sido el único punto de apoyo que ha sostenido y sostiene a esta América del sur, [eso] nadie me lo puede oscurecer" ${ }^{48}$

Sin las ataduras liberales y consciente de que la abolición de la Constitución no necesariamente implicaba una vuelta al Antiguo Régimen, Calleja pudo implantar aquello que Juan Ortiz ha denominado la "dictadura militar", basada en la aplicación de su ley marcial y la militarización del orden público. ${ }^{49}$ Este tipo de absolutismo de corte castrense muy pronto entró en conflicto con los intereses de la Iglesia, la cual también vio en el nuevo contexto una oportunidad para reforzar sus posiciones. ${ }^{50}$ La colisión de intereses nos revela las profundas diferencias en los proyectos de los sectores que apoyaron el retorno del monarca en términos antiliberales. El virrey consideraba que los

${ }^{48}$ Las citas en O’Phelan, “Abascal y el fantasma de las conspiraciones”, pp. 121-146, esp. pp. 121-122. HAMNETT, Revolución y contrarrevolución.

49 Ortiz, Calleja, pp. 137-148. Sobre la preponderancia del poder militar sobre el civil véanse, también, Archer, “The Royalist”, pp. 65-82; НAMnETT, Raíces de la insurgencia, pp. 95-102; SERRANO, Jerarquía territorial, pp. 92-96 y Diego-Fernández y Gutiérrez, “José de la Cruz”, pp. 229-274.

50 Pérez Memen, El episcopado, pp. 81-145; Connaughton, Ideología y sociedad, pp. 133-165, y Rosas, "El Cabildo Catedral de Puebla”, pp. 156-182. 
eclesiásticos y sus bienes debían subordinarse a las directrices de su plan. Conocía el poder de persuasión del púlpito y el confesionario. No estaba por tanto dispuesto a dejar que los religiosos se constituyeran en una esfera de opinión autónoma, máxime cuando la rebelión había sido encabezada por un cura. Si agria fue la disputa que mantuvo con el obispo reformista de la diócesis de Michoacán, Manuel Abad y Queipo, el choque más nítido lo mantuvo con el de Puebla, Antonio Joaquín Pérez.

Este había sido uno de los diputados firmantes en la $R e-$ presentación y Manifiesto de los "Persas" y contribuyó a la delación de sus compañeros liberales. ${ }^{51}$ Además, desde 1805 fungía como comisario y calificador del Tribunal del Santo Oficio, al cual defendió en los debates de las Cortes de Cádiz que llevaron a su abolición. La fidelidad a Fernando VII le fue recompensada con la mitra angelopolitana el 19 de diciembre de $1814 .{ }^{52} \mathrm{~A}$ su arribo a Nueva España se puso en contacto con Calleja para recriminarle el uso de ciertas prácticas que se estaban produciendo con el pretexto de la causa militar. Tratando de intimidarle, se presentó como "hacedor de virreyes” e insinuó que la Regencia lo había nombrado gracias a sus recomendaciones. Se consideraba entonces con suficiente autoridad moral para recriminarle los abusos que se habían cometido durante su gestión, especialmente perceptibles en el uso inadecuado de los diezmos. El virrey llegó a reconocer algunos, pero estos quedaban plenamente justificados a la luz de los acontecimientos: "las leyes de la guerra autorizan cualquier exceso, y el alzamiento de Nueva España sin causa ni apariencia de razón contra sus padres era uno de ellos”. Las autoridades necesitaban recurrir a todos los recursos disponibles para afrontarlo y los bienes eclesiásticos no eran una excepción.

${ }^{51}$ Los otros novohispanos suscritores fueron Ángel Alonso y Pantiga, por Yucatán, José Cayetano Sanmartín, por Guadalajara, y José Cayetano de Foncerrada, por Valladolid de Michoacán.

${ }^{52}$ Gómez, El obispo Pérez. 
Pérez discrepaba. Por importante que fuera la contienda nunca se alcanzaría una victoria definitiva si no se respetaba a la Iglesia en todos sus privilegios. Sin la religión no había gobierno posible ni reino que se sustentara..$^{53}$ Esta reivindicación de una completa autonomía respecto del poder civil pone de relieve hasta qué punto la asunción de posiciones ultramontanas en Nueva España afloró en personajes como el obispo poblano antes del contexto de la independencia en los años veinte. ${ }^{54} \mathrm{Tan}$ peligroso podía resultar un liberalismo interventor en materias eclesiásticas como el absolutismo regalista.

Como ha podido observarse, la propuesta pactista de los "Persas", la patrimonialista de Fernando VII, la castrense de Calleja y la ultramontana de Pérez discrepaban sobre el rumbo que se debía tomar, más allá de un consenso básico en torno de los marcos de referencia tradicionales. Todas partían de presupuestos antiliberales, aunque las diferencias entre sus proyectos de Restauración resultan más que evidentes. Pero a pesar de las controversias aquí esbozadas, los publicistas de la contrarrevolución en Nueva España se lanzaron a una campaña propagandística en la que trataron de mostrar el advenimiento de un tiempo nuevo para el trono y el altar. No es que las distintas concepciones sobre la organización de la Monarquía desaparecieran, pero es cierto que las diferencias pasaron en el plano discursivo a una posición bastante secundaria, aflorando solo en algunos aspectos concretos, aunque reveladores. Lo importante era presentar la supuesta vuelta al orden tradicional como el mejor de los escenarios posibles. De ello dependía aumentar los apoyos

53 Antonio Joaquín Pérez a Félix María Calleja, Puebla (14 de abril de 1816); AGN, Instituciones coloniales, Infidencias, 15317, vol. 117. Ya con anterioridad el cabildo de Valladolid, en la diócesis de Michoacán, se había dirigido al virrey Calleja quejándose de que los comandantes militares estaban tomando los diezmos "como cosa propia”, tal y como explica Ibarra López, “Diezmos y guerra”, pp. 29-54, esp. 46-51.

${ }^{54}$ Gómez, “La iglesia poblana”, pp. 55-75. 
sociales, consolidar los resortes del poder virreinal y mostrar las contradicciones del ideario insurgente.

\section{EL TIEMPO DE LA RESTAURACIÓN}

El trono y el altar constituían las dos caras de una misma moneda en los variados discursos legitimadores del periodo que se abrió a partir de 1814. Examinar esa interrelación -y sus resquicios- puede ayudar a una mejor comprensión de los imaginarios del momento que, en buena medida, guiaron las decisiones políticas para recuperar las cotas de poder perdidas. Por medio de los documentos consultados hemos seleccionado los principales elementos que aparecen en ellos y sobre los que se quiso sustentar el regreso del monarca. Esta construcción ideológica se hacía descansar sobre fundamentos religiosos, histórico-patriotas, jurídicos, e, incluso, en un supuesto apoyo de las clases populares. Se trata de argumentos retóricos de diversa índole y naturaleza que, en ocasiones, se presentan combinados en un mismo documento para reforzar las ideas que se presentaban al público.

La retórica sacralizadora quiso demostrar que se trataba de un rey elegido por la Providencia para liberar al conjunto del orbe cristiano de la opresión al que les había sometido Napoleón, vocero de los falsos filósofos enemigos del catolicismo y de las monarquías. En una composición poética, el Dr. Agustín Pomposo Fernández de San Salvador explicaba cómo el monarca había hecho frente al emperador dando una muestra de su gallardía: "Moriré, pero siendo rey de España” le dijo bizarramente. La verdad era incontestable: "Fernando es el justo por quien / viene la libertad a Europa toda entera: / ved ¡qué Rey tan amable se os destina!”. ${ }^{55}$ Según el cura José Ma Zapata, las

55 Fernández de San Salvador, Fernando VII en España, pp. 11 y 13. Los poemas aparecen firmados el 30 de mayo de 1814. Sobre el autor, Hamill, “The rector", pp. 49-61. 
furias de la revolución habían sido liberadas por el propio Dios para castigar los excesos cometidos por su grey y hacer posible el ciclo de la regeneración. Este había enseñado a las tropas francesas cómo atravesar los Pirineos para que ocuparan la península, al igual que en América dispuso que la guerra destrozara intestinamente a los hermanos que habitaban su suelo. La equiparación le resultaba evidente: si la Providencia atizó a Jerusalén por sus injusticias, los territorios de la Monarquía española merecían un escarmiento similar, pues estos "florecientes reinos se habían empeñado en sobresalir a los demás por el abandono público de la religión, y el exceso de sus escándalos". ${ }^{56}$

El padre José Julio García Torres observaba que durante seis penosos años ese mismo Dios había hecho sentir “los golpes más terribles" y "el peso de su cólera" hasta el extremo. El secuestro del monarca había supuesto el punto más álgido del castigo. Parecía incluso que "no era ya el Dios de los españoles" y que, añadía, "sordo a nuestros clamores veía con fría indiferencia nuestras más lamentables desgracias". ${ }^{57}$ Pero su ira finalmente cesó y en medio de esa atribulada situación todos descubrieron que Fernando había sido seleccionado para poner coto a los males que afligían a la Monarquía. Para el obispo Antonio Bergosa y Jordán la suerte del rey era comparable a la del profeta David, al igual que el destino de España al de Israel. La ruina de los territorios era solo un estado previo que consentía la Providencia para mostrar después todo su poderío. Una pequeña comparación bastaba para probar los nexos entre ambos pueblos: "si cotejamos la historia de los israelitas con la de los españoles, diremos ciertamente que en ambos pueblos han precedido los pecados a los castigos". Pero, continuaba, "por fin Dios ha sido el protector de aquellos así como de nosotros, y que tanto en los

56 ZAPATA, Sermón moral, pp. 9, 16, 17 y 18; CEHM-CARSO, núm. de inventario 022675, observaciones: miscelánea sermones núm. 7, folleto 7.

57 García Torres, José Julio García Torres, p. 2; BNM-FR, Lafragua, núm. 156. 
combates como en las victorias el mismo Dios ha sido nuestro caudillo y defensa" ${ }^{58}$ Nadie podía dudar de que el retorno del monarca a la península había sido resultado de la intercesión de una fuerza superior y trascendente.

Desde su nacimiento Fernando había tenido que superar diversas pruebas. Primero hubo de enfrentarse con el despotismo interior de la corte que controlaba el valido de su padre, Manuel Godoy. Después, a la opresión exterior a que lo sometió el tirano de Europa. Finalmente, incluso los propios españoles se aprovecharon de su ausencia para usurparle la soberanía. Pero a pesar de los escollos, en cada uno de estos episodios había salido triunfante, augurando un reinado colmado de caudales. Cuando en 1808 subió al trono de sus ancestros aseguró que tomaría a la religión por bandera, tal y como recordó Jacinto Moreno y Bazo: "Desde tan feliz momento todos conciben esperanzas de su acertado gobierno”. No había dudas al respecto porque, añadía, "Fernando apenas recibe en su cabeza la Diadema del Imperio, cuando como otro Joás pone con ella el Libro de las Santas Escrituras". Ese mismo año, continuaba, los engaños y perfidias de Napoleón lo sometieron a un cautiverio que, sin embargo, todavía iba a realzar más la honestidad de sus acciones: "Fernando padecerá, pero para que como las estrellas por la noche, así resplandezcan sus virtudes en la oscuridad de su prisión". ${ }^{59}$ Hijos bastardos de la revolución francesa, los diputados gaditanos dieron los pasos necesarios para acabar con el benéfico reinado del monarca al que tenían jurado. José Mariano Beristáin de Souza no ahorró epítetos a la hora de definirlos como "filósofos impíos", "monstruos del liberalismo", "representantes fraudulentos", "lenguas injustas” o "discípulos

58 Bergosa y Jordán, Nos el Dr. D.... (19 jun. 1814), pp. 1 y 2; BDH. Sobre los avatares del personaje en este contexto se ha ocupado HAMNETT, "Antonio Bergosa y Jordán”, pp. 117-136.

59 Moreno y Bazo, Sermón de acción de gracias, pp. 12 y 13; BPEJ, sala jalisciense, núm. de miscelánea: 309, núm. de documento: 2 . 
fidelísimos del Tirano". Aprovechando que el pueblo se hallaba ocupado en la guerra, empezaron a "tender la red, a urdir la tela y a desparramar la semilla de [su] detestable sistema". Finalmente consiguieron su objetivo, esto es, hacer tragar "el bocado amargo de una indigesta democracia" en la que el soberano quedaba degradado al rango de un "Rey de Farsa" ${ }^{60}$ Uno y otro, rey y pueblo, se nos muestran cargados de ingenuidad e inocencia, fáciles de sucumbir al engaño.

La operación restauradora, a continuación, se sustentaba sobre unos derechos históricos que habían sido socavados por las Cortes. Tratando de unir el pasado con el presente, fray Juan González recordó el valor simbólico que tenía el monte Auseva, en Asturias, donde se encontraba el santuario de la virgen de Covadonga. Desde aquel reducto don Pelayo inició la conquista de la península contra los musulmanes. A su término, en tiempos de Isabel y Fernando, Dios les regaló el descubrimiento de un nuevo continente al que transmitir el catolicismo. Este, de hecho, se había convertido en la esencia de la Monarquía desde que, en el III Concilio de Toledo (589), el rey Recaredo abjurara del arrianismo. Aseguraba que por Fernando VII corría "sin interrupción la sangre Goda de D. Pelayo y D. Alonso el católico", trazando así un interesado continuum en el que hundir las raíces de su reinado hasta la noche de los tiempos. Siendo el rey valedor del mismo espíritu de aquellos que llevaron el país a sus cotas más elevadas de grandeza no podía sino esperarse ahora un destino similar. Un ayer completamente distinto al presente servía para sustentar un relato patriótico e identitario que dotaba de legitimidad el proyecto de recuperación del poder. ${ }^{61}$

\footnotetext{
60 Beristáin de Souza, Discurso, pp. IX y X; CEHM-CARSO, núm. clasificador: $972.03 \mathrm{VA}$, núm. inventario: 33320, observaciones: miscelánea guerra de la independencia, núm. 1, folleto 2. Una visión panorámica sobre los escritos de este eclesiástico en ZAYAS DE LiLle, “Los sermones políticos”, pp. 719-759. ${ }^{61}$ GonzÁlez, Sermón histórico-encarístico, pp. 50 y 65; CEHM-CARSO, núm. clasificador: $252 \mathrm{GON}$, núm. inventario: 35069.
} 
Unida a la soberanía absoluta y a los derechos del monarca se encontraba, en tercer lugar, la apelación a las leyes fundamentales del reino que avalaban jurídicamente la legitimidad del golpe de Estado. En la Representación y Manifiesto de los "Persas" abundan las referencias al expolio a que las Cortes sometieron dichos reglamentos: "no podía en ningún caso tratarse de leyes fundamentales nuevas; habiendo las antiguas, y más sensatas, con las cuales se había celebrado un pacto entre la Nación y el Rey". Esas antiguas e inconcretas ordenanzas tradicionales que Calleja consideraba desfasadas eran las que se estaban esgrimiendo para corroborar la plena autoridad de Fernando VII. $\mathrm{El}$ "antiguo despotismo" podía haber oscurecido o desviado el contrato originario por el que la soberanía fue cedida al monarca, pero esto no implicaba su cese. ${ }^{62}$ El obispo de Puebla también salió en su defensa. Esas leyes habían pasado "por el examen de muchos siglos" y su utilidad estaba comprobada por las experiencias previas. Frente a la tiranía de la Asamblea, el gobierno monárquico era el mejor de los existentes, pues promovía la unidad. Era, además, el único que hasta el momento habían conocido y en el que el rey actuaba como un padre de sus vasallos. Se trataba de un soberano que, según sus propias palabras, "de nada se manifiesta tan solícito, como de que se cumplan las leyes que promueven y aseguran la felicidad de los pueblos". ${ }^{63}$ En 1812 se había aceptado resignadamente la Constitución para evitar mayores males, pero ahora era el momento de reconocer a Fernando VII como único soberano legislador. ${ }^{64}$

Efectivamente, conociendo el carácter paternalista y protector de su soberano, no extrañó a los publicistas que fuera el

\footnotetext{
${ }_{62}$ Representación y Manifiesto, p. 24.

63 Pérez, Pastoral del obispo de la Puebla, pp. 25 y 26; CEHM-CARSO, núm. clasificador: 252.12.72.49 VA, núm. inventario: 33578, observaciones: miscelánea cartas pastorales Puebla, núm. 2, fol. 16, colección Puebla.

${ }^{64}$ Fernández de SAN SAlvador, El modelo de los cristianos, pp. 2-25; BNMFR, RSM 1814 M4FER.
} 
pueblo sano el primero que se levantó para defender a su rey. En último lugar, se interpretaba que el apoyo popular suponía una fuente de autoridad irrefutable, tal y como quedó demostrado el 2 de mayo de 1808. Fray Josef del Salvador, predicando delante del rey, le recordó que fueron los lugareños quienes, por mediación divina, salieron a su encuentro. Envueltos en lágrimas de amor le entregaron todo aquello que poseían con el único objetivo de asentarle en el trono de sus antepasados: "te ofrecie[ron] su corazón, su vida, sus haciendas, sus carros, sus bestias, sus caballos, sus coches, hasta tirar del tuyo una multitud de heroicas y honestísimas doncellas". También los militares contribuyeron a la causa. Olvidando el estado de abatimiento en el que se encontraban, dispuso la Providencia que "electrizasen la Nación a tu favor" mediante el reconocimiento de la plena capacidad soberana. ${ }^{65}$

Pero ese mismo pueblo, aseguraba Beristain de Souza, podía ser "seducido" y “engañado", tal y como había ocurrido en Nueva España. Los discípulos de los sofistas ilustrados coreaban por todas partes que "no debe reconocerse a Fernando por rey, sino al apóstata Hidalgo, al Judas de la Nueva España, al Barrabás de la América" ${ }^{66}$ Para los realistas contrarrevolucionarios, el discurso insurgente estaba ahora mostrándose con el rostro descubierto ${ }^{67}$ Resultaba una contradicción haberse sublevado en nombre del rey y mantener la vía armada cuando este había sido liberado. Era, además, un atentado contra su "herencia", tal y como lo recordaba el padre García Torres. Este reconocía que solo con su rendición se podría restablecer definitivamente la estabilidad que necesitaba el conjunto de la Monarquía: "Unidos por religión por honor y por amistad, unos y otros españoles, formaremos una nación, un pueblo y un pueblo el más dichoso

\footnotetext{
${ }^{65}$ Salvador, Sermón, pp. 11 y 12; BNM-FR, RSM 1815 M4SAL.

${ }^{66}$ BeristáIn de Souza, Discurso cristiano, p. 18; BDH.

67 Un análisis profuso sobre el particular en LaNDAvazo, La máscara de Fernando VII. También Hamill, The Hidalgo Revolt.
} 
del universo". ${ }^{68}$ Bergosa y Jordán, por su parte, les planteó una clara disyuntiva ante la que no podrían mostrar ambigüedad alguna. De ello dependía su futuro y el del propio territorio:

No hay más que dos extremos: o ser fieles a la Monarquía Española, o declararse enemigos de Dios y de Fernando. Si elegís lo primero, este es el tiempo de deponer y rendir las armas, y de sacar ventajas [...] implorando indulto, pero si elegís lo segundo sobre descubrirse más vuestras falsedades y embustes, y las felonías de vuestro corazón y capricho movido del tirano de la Europa, seréis también confundidos como él, porque Dios que nos ha librado de aquel, tomará así mismo la más sangrienta venganza de vosotros. ${ }^{69}$

Era el momento de que aprovecharan la bondad del monarca y el espíritu de reconciliación de que, decían, había dado muestras. De hecho, este mismo ánimo fue el que manifestó respecto a la religión, el otro gran puntal en el que se apoyaba la Restauración. Según apuntan las fuentes examinadas, Fernando VII accedió graciosamente a la reposición de los dos pilares tradicionales en la salvaguarda de la fe: la Compañía de Jesús y el Tribunal de la Inquisición. En ambos casos se observa cómo su regreso dio pie a que se interpretara el presente como la vuelta a los tiempos gloriosos que el catolicismo alcanzó en el siglo xvi. Con ello se pretendía obviar conscientemente aquellas etapas en las que la Iglesia había sido objeto de un mayor embate regalista, remontándose a un pasado supuestamente dorado de coexistencia perfecta entre el poder civil y el religioso, aunque presumiéndose la preeminencia de este segundo. Este recurso permitía conectar una vez más distintas escalas temporales que posibilitaban de manera eficaz proyectar sobre el futuro las glorias de un pasado poco sujeto al régimen de historicidad, lo

68 García Torres, José Julio García Torres, p. 6.

69 Bergosa y Jordán, Nos el Dr. D... (19 jun. 1814), pp. 17 y 18. 
cual da buena cuenta del carácter mítico que llegó a alcanzar el proyecto restaurador.

La reposición pública de los jesuitas en Nueva España fue promovida económica y políticamente por la familia Castañiza y se produjo el 19 de mayo de 1816 en el Colegio Real de San Ildefonso de la Ciudad de México. Desde que se habían tenido noticias del restablecimiento de la Compañía por parte del papa Pío VII y del rey, las autoridades virreinales y las principales organizaciones de la capital emprendieron iniciativas activas para que la Orden se restableciera. Junto a escritos y peticiones a Fernando VII cabe señalar, por ejemplo, la formación de una junta de protección de la Compañía de Jesús. ${ }^{70}$ De una u otra forma, todos aquellos que festejaron la vuelta de los ignacianos iban a ensalzar su papel como protectores de la religión y educadores. Fernández de San Salvador recurrió a los principales representantes del pensamiento reaccionario europeo para explicar las causas que llevaron a su extinción en $1767,{ }^{71}$ hecho que demuestra la perfecta circulación de las ideas presente entre los intelectuales de la contrarrevolución. Nicolás-Silvestre Bergier, Claude-François Nonnote, Fernando de Cevallos, Agustín Barruel o, incluso, François-René de Chateaubriand -cuyo Génie du christianisme (1802) se difundió entonces en Nueva España- ${ }^{72}$ le servían para demostrar los planes contra el altar y el trono que tramaron los falsos filósofos. ${ }^{73}$ Desde la fundación de la Compañía, aseguraba, los ignacianos habían sido el principal baluarte de los poderes civiles y religiosos, de ahí que

70 Hamnett, Revolución y contrarrevolución, pp. 224-228; Zermeño, “El retorno de los jesuitas", pp. 1463-1540, esp. pp. 1468-1477. Sobre la continuidad del imaginario jesuítico se ha ocupado Bernabéu, "El vacío habitado", pp. 1261-1303. Para el caso peninsular pueden verse Revuelta, El restablecimiento y Luengo, Diario.

${ }^{71}$ Fernández de SAN SAlvador, Los jesuitas quitados; BDH.

72 Gaceta del Gobierno de México, núm. 812 (26 oct. 1815), p. 1150.

73 A excepción del último autor, el resto fueron estudiados por Herrero, Los orígenes, pp. 35-53, 91-104, 181-218. 
fueran las primeras víctimas de su conspiración universal contra las autoridades. La correspondencia que mantuvieron Voltaire y D'Alembert con Federico II de Prusia daba buena cuenta de sus planes. ${ }^{74}$ Acabar con la Orden se convirtió en una operación que se consideraba un triunfo que quedaría marcado en la historia de la humanidad: "la destrucción de los jesuitas - decía el filósofo de Ferney- no solamente sería época en la historia de la Iglesia, sino que formaría una verdadera era cronológica, desde la cual la filosofía debería empezar a contar sus años". Si bien Dios había permitido el regreso de la Compañía para salvar la tierra, primero coordinó su extinción entre los planes del castigo. La situación que entonces se vivió en todo caminaba a la consumación del fin de los tiempos que describió el evangelista:

El mundo todo conjurado y enfurecido por el ateísmo, deísmo y materialismo, que con impudencia se jactaban del triunfo que lograron por la expatriación y extinción de los jesuitas: el mundo todo convertido en ruinas amalgamadas con torrentes de sangre y lágrimas, presenta al ojo que ve sin la preocupación del filosofismo impío, el teatro muy parecido al que vio San Juan, como en demasía próximo al terrible postrero día en que el Crucificado juzgará por la última vez a toda la descendencia de Adán. ${ }^{75}$

Sin embargo, el retorno de los expatriados se presentaba como una estabilización del tiempo histórico. Para el padre Ignacio Lerdo de Tejada su recibimiento se asemejaba a la acogida

\footnotetext{
${ }^{74}$ Sin mencionarlo, estaba obteniendo la información de un Artículo comunicado a el Procurador General del Rey y de la Nación, en defensa de los jesuitas, México, Imprenta de doña María Fernández de Jáuregui, 1814; quien, a su vez, tomaba buena parte de sus argumentos del opúsculo de Lorenzo Hervás y Panduro titulado Causas de la Revolución de Francia en el año 1789 y medios de que se han valido para efectuarla los enemigos de la religión y el Estado, Madrid, 1807.

75 Fernández de San Salvador, Los jesuitas quitados, pp. 11 y 22.
} 
que tuvieron en la decimoquinta centuria. De hecho, Ignacio de Loyola nació tan solo un año antes de que se descubriera América. ¿Quién podía negar las conexiones? Era de esperar que los beneficios que entonces se concedieron a la Iglesia por medio de sus discípulos fueran ahora continuados por sus sucesores. ${ }^{76}$ Esta era la idea que se sostuvo en otro sermón con motivo de la restitución de los ignacianos. Según apuntaba el orador, desde que estos habían vuelto a Nueva España los jóvenes clamaban por entrar a formar parte de la Compañía y aprender de sus miembros. Ello era un síntoma de que en un futuro inmediato el virreinato iba a contar con un nutrido grupo de nuevos jesuitas que se encargarían de pacificar a los pueblos, reducir a los rebeldes, extender el catolicismo y predicar la subordinación debida al monarca y al papa. ${ }^{77}$

El restablecimiento del Tribunal del Santo Oficio en Nueva España no estuvo exento de polémica, pues tanto Calleja como la Audiencia retardaron su instalación celosos de que ello implicara perder alguna cota de su poder. El bando de reposición se emitió en enero de 1815, pero ello tampoco zanjó las disputas, pues el inquisidor Manuel Flores muy pronto arremetió contra el virrey y los oidores al entender que ambos se estaban entrometiendo en aspectos que no les incumbían. ${ }^{78}$ Pero más allá de estas evidentes desavenencias, en el ámbito de los discursos la Inquisición se presentaba como un complemento de lo que suponía la presencia de los jesuitas en el virreinato. Según Bergosa y Jordán, Fernando VII recordó que en el siglo xvi España había sido próspera gracias al Tribunal, que evitó la contaminación del país. Si la religión era el principal soporte de las "virtudes

\footnotetext{
76 Lerdo de TejadA, Discurso, pp. 5 y 25; CEHM-CARSO, núm. clasificador: 041.V.A, núm. inventario: 48173-A.

77 Díaz Pérez y Calvillo, Elogio..., p. 36; BNM-FR, RSM 1816 M4DIA.

78 Hamnett, Revolución y contrarrevolución, pp. 232-237; TorRes PugA, “El último aliento”, pp. 77-105 y QuEZADA, ¿Una Inquisición constitucional? Para el caso peninsular, LA PARra y CASAdo, La Inquisición en España.
} 
políticas y sociales", resultaba evidente el papel que desempeñaba la institución encargada de velar por la pureza de la fe en la conservación de cualquier monarquía. "El trono -asegurabapara su prosperidad ha contado precisamente con los auxilios del altar; y caminando de acuerdo [...] conspiran uniformes a la felicidad de los pueblos, y a la conservación recíproca de la religión, del trono y de la patria”. En esta situación de dependencia los cetros y las coronas solo podían brillar si se rendían a la "suavísima dominación" de los "derechos sacrosantos de Jesucristo" ${ }^{79}$ Es más, hubo quien incluso se preguntó retóricamente si resultaba más importante la restitución del rey o la de la Inquisición. La realidad no era sencilla de ponderar. Fernando VII era "el único centro de la unidad de la monarquía", pero el Tribunal se encargaba de custodiarla. ${ }^{80}$

La apología más importante del Santo Oficio en Nueva España fue elaborada por fray José de San Bartolomé antes de conocer su reposición, aunque al final de la misma ya diera noticias de saberlo. Este apuntó que el trono y el altar habían llegado a estar enfrentados en una lucha histórica entre universalidades, de manera que solo la Inquisición sirvió de argamasa a la hora de sellar la alianza. Sin ella nada se podía hacer para refrenar a los francmasones e incrédulos, mucho peores que las sectas antiguas: "¿quién podrá jamás persuadirse, que toda la malicia judía y morisca [...] pueda compararse con el grado más ínfimo de estas?". ${ }^{81}$ El objetivo de las Cortes de Cádiz no fue otro que allanar el camino a los conspiradores, de ahí que aprobaran el

79 Bergosa y Jordán, Nos el Dr. D... (31 dic. 1814), pp. 1 y 2; BDH.

80 Carrasco y Enciso, Sermón eucarístico, p. 28; BNM-FR, RSM 1809 M4MOR.

${ }^{81}$ SAN BARTOLOmÉ, El duelo de la Inquisición, pp. 6 y 23; BDH. En la península se publicó bajo el siguiente título: El duelo de la Inquisición o pésame que un filósofo rancio de la América septentrional da a sus amados compatriotas los verdaderos españoles por la extinción de tan santo y utilísimo Tribunal, Madrid, don Francisco Martínez Dávila, 1814; BNE, 1/1775. 
decreto de extinción del Tribunal. Así trataba de demostrarlo en la segunda parte del opúsculo, entrando a debatir con los diputados Joaquín Lorenzo Villanueva y Antonio José Ruiz de Padrón. ${ }^{82}$ Ambos defendieron la supresión de la Inquisición en su apuesta por un retorno a los tiempos del catolicismo primitivo y por reforzar la autoridad de los obispos dependientes del poder civil..$^{83} \mathrm{El}$ padre San Bartolomé, en contraposición, apelaba por reforzar el vínculo con la Santa Sede, a quien solo tocaba introducir reformas en las cuestiones de la Iglesia. Las razones eran evidentes: "Si la potestad real es absoluta, independiente y suprema en su línea, otro tanto se dice de la eclesiástica". También este religioso vinculaba los tiempos en que se instauró el Tribunal con el glorioso descubrimiento del nuevo mundo. Consecuentemente, su retorno se presentaba como el eslabón necesario para que regresara "todo el esplendor católico anexo a antecedentes tan executivos". Roma era la "matriz y centro de la religión", pero la nación española estaba predestinada a expandir el catolicismo hasta los confines del mundo conocido. ${ }^{84}$

Las críticas al papel desempeñado por los frailes durante el periodo gaditano fueron respondidas por el padre José María Orruño. Aquellos que los tachaban de ociosos, ladrones o fanáticos supersticiosos desconocían la misión histórica que desempeñaron en la dilatación del catolicismo y su defensa, así como en la ilustración de la Iglesia y de los pueblos. Desde el siglo XIII se encargó a estos eclesiásticos la tarea evangelizadora. Incluso hubo momentos en los que fueron por delante de los procesos de conquista. La historia demostraba que cada vez que la Iglesia se vio amenazada por las herejías Dios fomentó la creación de nuevas órdenes regulares, "que sacad[a]s del tesoro de

82 SAN BARTOLOMÉ, El duelo de la Inquisición, pp. 57-198.

83 Sus obras antiinquisitoriales se difundieron en la ciudad de México junto a la Discusión del proyecto de decreto sobre el Tribunal de la Inquisición, tal y como señala Torres Puga, "El último aliento", p. 83.

84 SAn Bartolomé, El duelo de la Inquisición, pp. 60, 201 y 203. 
sus misericordias han sido escuadrones bien ordenados que han peleado sus batallas" ${ }^{85}$ En un momento de crisis como en el que se encontraba Nueva España era necesario reforzar el papel de los frailes si se quería acabar con la rebelión. Máxime si se tenía en cuenta que en buena medida fue excitada por eclesiásticos que debían ser reconvenidos, al igual que los feligreses descarriados. Si ellos habían conseguido los mayores triunfos para la Iglesia resultaba una evidencia que la recomposición político-religiosa se proyectara sobre su sostenimiento y refuerzo.

El último componente que integraba el constructo ideológico que estamos examinando fue la liberación de Pío VII, cuya entrada en la Ciudad Eterna se produjo el 24 de mayo de 1814. Desde luego, no resultó una operación sencilla explicar la trayectoria de un papa que no solo llegó a acuerdos con Napoleón Bonaparte, sino que estuvo presente en su ceremonia de coronación. Los escollos fueron salvados por el chantre Ignacio Mariano Vasconcelos en los siguientes términos. El sumo pontífice siempre actuó por el bien de su Iglesia, lo cual lo impelió a contemporizar en determinados aspectos. Sin embargo, aceptar al nuevo emperador no significaba rechazar los derechos al trono que tenía Luis XVIII. De hecho, la calma se mantuvo hasta que Napoleón quiso que lo apoyara en el destronamiento de los otros soberanos europeos. Su oposición lo llevó entonces al cautiverio, hasta que la Providencia, escuchando los clamores de la grey, lo liberó. El nombre que había elegido para su pontificado no era casual, pues si a mediados del siglo xvi Pío V tuvo que enfrentarse a los protestantes, “al acabar el 18 y principiar el 19 otros medios [le] han sido indispensables” para imitarlo. Los enemigos de la religión pensaron que podrían acabar con la cabeza visible de la cristiandad, pero obviaban el arrebato con el que había sido ungido como "Restaurador de la Iglesia". ${ }^{86}$

85 Orruño, ¿Para qué sirven los frailes en el mundo?, p. 21; BNE, HA/23890.

86 Vasconcelos, Sermón, pp. 13-20. 
En términos generales, el ciclo parecía estar prácticamente completado. Junto a la Inquisición y la defensa de las órdenes religiosas, el Dr. Fernández de San Salvador fue claro en el diagnóstico que se aventuraba como resultado de la suma de las partes aquí examinadas: "Así es que la restitución de la Compañía de Jesús, no menos que la ruina del corso y que la libertad de Pío y de Fernando, debe fijar la época gloriosa del exterminio del filosofismo y mirarse como una parte esencial del nuevo plan que la Providencia divina coordinó para remediar el mundo". ${ }^{87}$ Pero si los sofistas enemigos del altar y del trono habían sido momentáneamente aplacados en Europa, sus discípulos americanos continuaban declarando la guerra a las legítimas autoridades repuestas. Nuevos recursos se precisaban para hacerles frente.

\section{“UNA NUEVA RAZA DE FILÓSOFOs”}

La vuelta al orden natural que los realistas vieron colmarse con los elementos que acabamos de examinar y la denuncia de los planes insurgentes formaban parte de un mismo programa político-ideológico. Este muestra la complejidad del momento histórico en el que nos encontramos y los esfuerzos realizados para adaptar los discursos a una realidad atravesada por la guerra civil. Todos fueron conscientes de que la Restauración no podría efectuarse por completo en Nueva España sin la derrota de los sublevados. Lejos de observarse en los documentos una condena inerte y repetitiva, la experiencia previa había mostrado suficientemente la necesidad de actualizar los campos de intervención e introducir aquellos cambios que fueran menester, aunque ello implicara situarse en el campo de los contrarios. En este sentido, vale la pena insistir en que la crítica contrarrevolucionaria debería ser tenida más en cuenta para conocer mejor los proyectos y

87 Fernández de San Salvador, Los jesuitas quitados, p. 64. 
las bases intelectuales de los liberales e insurgentes de lo que la historiografía ha dado muestras hasta ahora.

Junto a la ofensiva armada, las tácticas que el gobierno virreinal y los intelectuales realistas utilizaron para hacer frente a la insurgencia fueron diversas. La Gaceta del Gobierno de México, por ejemplo, se convirtió en una plataforma idónea para dar publicidad a todo tipo de actuaciones: juicios, indultos y arrepentimientos -verdaderos, forzados o impostados- $; 8$ actas de fidelidad de los ayuntamientos al rey; ${ }^{89}$ descripción y ensalzamiento de combates o, entre otros, reprimendas variadas. El objetivo era crear un clima de opinión favorable a la causa fidelista. Se buscaba tanto desengañar a los que persistían en la contienda como confirmar a los leales que el final de sus enemigos se encontraba cercano, aunque fuera preciso persistir en la lucha. A partir de 1814 se intensificó la idea, perceptible desde 1810, de que los insurgentes descendían directamente de los falsos filósofos del viejo continente..$^{90}$ En términos genealógicos eran los nietos herederos de una Ilustración mal entendida, a la vez que hijos bastardos de los afrancesados y los liberales. Muy pronto se lanzaron a probar estas conexiones. Ello resulta especialmente visible tras la promulgación del Decreto Constitucional para la Libertad de la América Mexicana en el Congreso de Chilpancingo reunido en Apatzingán el 22 de octubre de 1814. Allí, como es conocido, se dio el paso definitivo del autonomismo a la proclamación de independencia bajo la fórmula republicana. Desacreditar este desafío legal se convirtió en una prioridad. En su edicto de 26 de mayo de 1815 el deán y el cabildo de la

${ }^{88}$ Herrejón, Los procesos de Morelos y Landavazo, La máscara de Fernando VII, pp. 268-274.

89 Ramírez, "Las «Actas de Fidelidad»", pp. 215-240.

90 Fernández de SAN Salvador, El modelo de los cristianos, pp. 59-124. Sobre el potencial de la interpretación puede verse HERrEjón, Del sermón al discurso civico, pp. 287-315; y Olveda, Los discursos opuestos. También, Terán, "La Virgen de Guadalupe", pp. 92-129. 
iglesia metropolitana de México instaron a que el conjunto de los eclesiásticos combatiera a los insurgentes en todos los campos y sentidos.

Pero no solo los religiosos acudieron a la llamada. El teniente coronel Francisco María Colombini explicó que se hallaba impedido para luchar físicamente contra los enemigos del trinomio compuesto por Dios, Rey y Patria. A cambio, había tomado la pluma para combatirles por medio de la palabra. Se trataba de mostrar al público cuáles eran los orígenes de semejantes planes:

¿No es así, que los réprobos doctores

de la impiedad, filósofos altivos, o más bien unos necios ignorantes, de las dos Potestades enemigos, os han dictado el horroroso infame, lleno de iniquidad y de delirios, escandaloso Código que ofende a Dios y a los Monarcas? Así ha sido; pues vuestras aserciones infernales, vuestros negros proyectos son los mismos de un Hobbes, de un Rousseau y de un Helvecio $\mathrm{y}$ de otros condenados libertinos. ${ }^{91}$

En todos sus movimientos se observaban los vínculos con los filósofos ilustrados. Pedro González de Araujo y San Román fue el encargado de elaborar la refutación más importante del Código de Apatzingán y buscó sus raíces en el artículo sobre "España” que elaboró Masson de Morvilliers para la sección de "Geografía Moderna" en la Enciclopedia Metódica (1782). ${ }^{92}$ En dicho apartado, Morvilliers criticó los atrasos del país y dejó incluso la puerta abierta a que algún día sus colonias tomaran

91 Colombini, Invectiva, pp. 3 y 4.

92 González de Araujo y San Román, Impugnación; BNE, HA/17513. 
un camino autónomo. En el horizonte inmediato no pareciera previsible la ruptura con esa "nación perezosa”, pero afirmaba que "sería sin duda un acontecimiento muy singular si América se sacudiese el yugo de España”. ${ }^{93}$ Atendiendo a estas consideraciones, González de Araujo entendía que el plan de independencia que abanderaban los insurgentes no era realmente nuevo. Desde el setecientos había estado rondando en la cabeza de los modernos sofistas, aunque solo ahora se manifestara sin rebozos. El obispo Manuel Abad y Queipo veía que una fuerza misteriosa era la ejecutora de sus proyectos. Ninguno de los actuales cabecillas era consciente de estar al servicio de un poder superior que acabaría fagocitándolos: "Morelos, Cos, los Rayones, ni esa congregación de idiotas que se titula Junta Nacional” conocían ser "los instrumentos de la mano oculta que promueve la independencia de la Nueva España, la cual romperá y destinará al fuego estos instrumentos cuando ya no los necesite". ${ }^{94}$ El inquisidor Manuel Flores tenía claro que se trataba de "una nueva raza de filósofos". ${ }^{95}$

Las redes urdidas por los francmasones les servían para propagar sus planes encaminados a la liberación del género humano. Incluso el prelado michoacano se mostraba capacitado para dar nombres. En un informe al rey del 20 de julio de 1815 le explicaba cómo había llegado hasta Veracruz, Xalapa y México una sociedad llamada los "racionales caballeros" por medio de Vicente Acuña, iniciado en Cádiz. La capacidad de estas logias para infiltrarse entre la población era máxima, pues en Nueva España “manejó desde el principio la gran masa del pueblo, indios, negros y mulatos, con suma destreza”. En menos de 15 días "más de un millón de habitantes" pasaron de "hombres sumisos y pacíficos" a "monstruos feroces que todo lo metieron a sangre

93 Documento recogido en La polémica, pp. 47 y 48.

94 La representación está fechada el 19 de febrero de 1815 y recogida por Torre VIllar, La independencia, pp. 110-112.

95 Gaceta del Gobierno de México, núm. 763 (11 jul. 1815), p. 728. 
y fuego". ${ }^{96}$ No resultaba difícil comprobar fehacientemente que el altar y el trono eran los blancos preferidos de los sectarios. Para Calleja, el Decreto Constitucional de Apatzingán bebía directamente de la Carta gaditana de 1812, pues aseguraba estar compuesta "de retazos de la Constitución angloamericana y de la que formaron las Cortes Extraordinarias de España". ${ }^{97}$

Aunque se tratara de una impugnación general, de los 242 artículos que contenía el Decreto, solo 5 entradas merecieron una atención especial por parte de González de Araujo para cuestionar las bases políticas y religiosas del ideario insurgente. Respecto a las primeras, entendía que reconocer que la soberanía "reside originariamente en el pueblo y su ejercicio en una representación nacional” (art. 5), capaz de "establecer el gobierno que más les convenga, alterarlo, modificarlo y abolirlo totalmente, cuando su felicidad lo requiera" (art. 4), era un atentado contra el principio de autoridad que solo conducía a la anarquía. No escapaba a su observación que los grandes impíos de la historia guiaban el ánimo de semejantes afirmaciones: "La obediencia debida al Rey ni pende de la voluntad y arbitrio de los vasallos, como dice Lutero, ni lícitamente se puede faltar a ella, como enseñó Calvino, ni es solo debida por la fuerza, como [...] asegura Rousseau". Por el contrario, se trataba de una obligación consagrada en el Evangelio. Los reyes no dependían en ningún caso de los pueblos. Eran ministros de Dios, pero no resultado de un contrato social y artificioso. La voluntad de los insurrectos por acabar con cualquier mando quedaba más clara todavía en la entrada 26, donde se asentaba el carácter temporal de los empleados públicos y el derecho del pueblo "para hacer

\footnotetext{
${ }^{96}$ Manuel Abad y Queipo, "Informe dirigido al rey Fernando VII por... que se conoce por el nombre de su testamento, antes de embarcarse para España, llamado por aquel monarca, con las notas del autor", México (20 jul. 1815), recogido en Alamán, Historia de México, pp. 582 y 583.

97 Gaceta del Gobierno de México, núm. 742 (25 de mayo de 1815), p. 538. Sobre su suerte, OlvEdA, “Cádiz y Apatzingán”, pp. 126-133.
} 
que vuelvan a la vida privada”. El autor de la impugnación intuía que de esta idea se sirvieron los jacobinos franceses para guillotinar a Luis XVI. Reducido el monarca al rango de "clase de persona particular” quedaba sujeto a cualquier nueva ley del gobierno entrante, incluso la pena capital. ${ }^{98}$

No menos importante resultaba en este punto la apelación a los conceptos preferidos por los revolucionarios de todos los tiempos, es decir, "el goce de la igualdad, seguridad, propiedad y libertad” (art. 24). Especialmente interesantes para el análisis eran el primero y el último, pues sobre ellos se habían legitimado los modernos gobiernos. La crítica más audaz vino de la mano del padre San Bartolomé, quien los contrapuso a las virtudes de una joven que empezaba el camino de la vocación religiosa. La libertad de hacer que predicaban los sofistas no podía equipararse a la que enseñaba el catolicismo, basada en la obediencia y subordinación “a los padres y legítimos superiores”. De la misma forma, la igualdad resultaba también una "quimera" de naturaleza "diabólica y viciosa" destinada a confundir todas las jerarquías sociales. Ambas eran los pilares sobre los que se levantaron "suntuosos torreones de viento, magníficas basílicas de perspectiva, artificiosos edificios de arquitectura". ${ }^{99}$ Todo un delirio de las mentes revolucionarias.

Por su parte, para González de Araujo el asalto a la Iglesia que llevaron a cabo los insurgentes no fue menor que el que padeció el poder civil. El cuestionamiento al que sometieron al orden religioso tradicional ${ }^{100} \mathrm{iba}$ a encontrar una condena tajante en su Impugnación. Consideraba que sin autoridad alguna se habían atribuido competencias que no les incumbían, estableciendo un vicario general castrense y permitiendo la administración

98 González de Araujo y San Román, Impugnación, pp. 8, 9, 28 y 29.

99 SAN BARTOLOMÉ, El liberalismo y la rebelión, nota 7 y pp. 10 y $17 ; \mathrm{BDH}$.

100 Ibarra, “"La justicia de la causa insurgente»”, pp. 63-80, esp. pp. 75-79; y Connaughton, “¿Politización de la religión o nueva sacralización de la política?”, pp. 160-200, esp. pp. 165-167. 
de sacramentos, oficiar matrimonios, reformar el calendario y hasta la recolección de los diezmos para sus arcas "nacionales". Además, incluso se habían atrevido a rechazar las excomuniones que les fulminaron los juiciosos prelados. Los responsables de semejante cisma habían sido José María Cos y José de San Martín, quienes actuaron al estilo de Enrique VIII de Inglaterra. Se presentaban como firmes defensores del catolicismo, pero solo buscaban barrenarlo. Aunque hubieran dispuesto que solo protegerían a aquellos "transeúntes" que reconocieran -junto con la soberanía nacional- el respeto a "la religión católica, apostólica y romana" (art. 17), su brújula apuntaba en otra dirección. ¿Acaso podrían negarles la libertad de "pensar, hablar, escribir y obrar a su arbitrio" que ellos mismos se tenían dada? ${ }^{301}$ Poco tiempo después de ser nombrado obispo de Sonora en 1817, fray Bernardo del Espíritu Santo recogía estas inquietudes al afirmar rotundamente que los insurgentes habían instaurado una "nueva iglesia" ajena a la que dependía de Roma:

En todas las revoluciones tumultuarias de los reinos, ha sido muy regular [...] la confusión y el desorden que ha conducido por sus pasos a los primeros motores a la ruina del Estado y de sí mismos, sin percibir de su rebelión otro fruto que el pesar de haberla promovido [...]. Pero jamás se había visto, sino en las tinieblas del gentilismo, colocar la impiedad en el trono de la religión. Los herejes han desplegado sus banderas atacando de frente algún misterio revelado, y por tanto no pudieron transformar la perfidia para que dejase de aparecer con toda su deformidad. Los americanos rebeldes se han revestido de otro aspecto al parecer más honesto, pero no es menos impío. ${ }^{102}$

101 González de Araujo y San Román, Impugnación, pp. 76-87.

102 Espíritu SANTo, Carta pastoral, pp. 7 y 17; BNAH, papeles sueltos $4^{a}$ serie, c. 1 , leg. 5 , doc. 7. 
Ningún Estado podía sobrevivir sin la uniformidad del culto y el verdadero catolicismo era la mejor guía para su mantenimiento. La independencia que estaban proyectando los insurgentes no solo era irrealizable, sino opuesta "a la expresada voluntad de Dios”, aseguraba el cura Manuel Toral en 1818. Francia instauró una república y nunca se vieron más desórdenes y tiranías. ${ }^{103}$ ¿Cuántas pruebas más necesitaban para desengañarse? Política, historia, jurisprudencia y religión daban la espalda a sus proyectos. Las armas tampoco les favorecían. Un monarca y una Iglesia reinstaurados en sus antiguos solios los esperaban con los brazos abiertos para que cesara la purga a la que la Providencia los había sometido. Los peninsulares ya estaban disfrutando los goces de esa nueva época y los novohispanos no podían permitirse naufragar, tal y como expresó fray Juan González, "en el Océano de las revoluciones políticas”. ${ }^{104}$

\section{CONCLUSIÓN: EL IMPOSIBLE RETORNO AL PASADO}

A lo largo de estas páginas hemos examinado los distintos materiales teóricos que sirvieron para construir en Nueva España el mito de la Restauración entre 1814 y 1816, especialmente. Se trató de un tiempo inédito en el que no llegó a producirse una "completa reposición del orden antiguo" o "retrogradación", como afirmó en su momento Lucas Alamán. ${ }^{105}$ Las incertidumbres que generó la orientación política que iba a tomar Fernando VII propiciaron que una pluralidad de propuestas surgiera a ambos lados del Atlántico dentro del absolutismo. Es preciso insistir en que la política autoritaria que emprendió el hijo de Carlos IV no debería llevarnos a minusvalorar la riqueza de las alternativas que inicialmente se formularon para hacer frente al

\footnotetext{
103 Toral, Pronóstico funesto, pp. 7 y 10; BNM-FR, Lafragua, núm. 327.

104 González, Sermón histórico-eucarístico, p. 58.

105 Alamán, Historia de México, pp. 113, 114 y 119.
} 
liberalismo, a las propuestas insurgentes y a la deriva despótica de la monarquía tardodieciochista. La homogeneidad con la que en ocasiones se presentó el periodo por parte de determinados publicistas contrarrevolucionarios contrasta con la diversidad de proyectos restauradores que se barajaron, más aún en un territorio donde se continuaba librando una guerra civil. La imagen del tiempo histórico estabilizado, que observamos en los discursos de aquellos, se encontraba en tensión con la que mostraban otros escritos que se pronunciaban contra la insurgencia. Entendían que solo con la derrota definitiva de los sublevados podría recuperarse el orden natural. Por su parte, tampoco deberíamos pensar que el rumbo que finalmente siguió el régimen impidió la formulación de cualquier tipo de demanda. El padre San Bartolomé, por ejemplo, propuso como remedio a los altercados que se vivían en ultramar elevar el número de criollos en el desempeño de los cargos públicos, "procurando de aquí adelante la continua mezcla de unos y otros, esto es, de americanos a España, de españoles a América, del cual modo por su peso producirá la igualdad casi aritmética de los oficios”. 106 Otra cosa distinta era que el monarca y sus virreyes estuvieran dispuestos a transigir.

La línea de futuro que los publicistas contrarrevolucionarios mentalizaron para asentar ideológicamente el constructo restaurador poco tenía que ver con el momento previo a la crisis de la Monarquía. El propio Antonio Joaquín Pérez señaló que aunque el rey hubiera dispuesto 1808 como un hito al que remitirse, "subiendo a épocas anteriores, verdad es que se encontraría menos angustiada, y si se quiere, más feliz la nación”. ${ }^{107}$ Pocos han puesto en duda que la revolución se proyectaba hacia el mañana tratando de instaurar un universo nuevo. Sin embargo, a la luz de lo expuesto, resulta igual de evidente que las propuestas

106 SAn BARTOlOmé, El liberalismo y la rebelión, nota 13.

107 Pérez, Pastoral, pp. 37 y 38. 
de sus contrarios no estaban ancladas en un mundo pretérito y estático. La utopía restauradora tuvo la virtud de conformarse sobre una red de relatos histórico-ficcionales -tanto positivos como negativos- que la dotaron de coherencia e impulsaron en medio de un contexto todavía inestable. La metáfora del "espejo deformado de esa revolución" nos remite a un escenario en el que dichos proyectos, en tanto que transgresores del pasado, en muchos aspectos resultaron tan novedosos como los principios que censuraban. La nostalgia de lo antiguo acabó por mostrar una nueva dimensión ideológica en la que fue preciso adaptarse al contexto, renovar los lenguajes e, incluso, incorporar parte de los cambios propuestos por los revolucionarios a la hora de combatirlos mediante sus propias armas retóricas. ${ }^{108}$

A pesar de las denuncias a la política y a los políticos modernos, lo cierto es que los realistas novohispanos entendieron perfectamente la necesidad de desplegar un activismo que apelara a los ciudadanos a la hora de lograr una verdadera movilización en términos contrarrevolucionarios. El reto que planteó el plan de independencia insurgente superó las amenazas que tuvieron que afrontar los antiliberales peninsulares y requirió desplegar sus armas específicas. En buena medida estas eran deudoras de aquellas que ya utilizaron ciertos autores antiilustrados del setecientos, aunque necesariamente reactualizadas a la luz de las nuevas circunstancias. En este sentido, el rearme discursivo de la Iglesia al que se asiste en este periodo será trascendental cuando la revolución vuelva a mostrarse en 1820 con unos planes secularizadores de mayor calado. El momento se presentó a partir de entonces, para ciertos sectores conservadores, como el idóneo para completar la operación restauradora, desde unos parámetros ideológicos nuevamente renovados y en

108 García Monerris y García Monerris, "Palabras en guerra”, pp. 139162, esp. p. 143. También, Compagnon, Los antimodernos. 
buena medida ajenos a las cargas liberales más radicalizadas que impulsaban las Cortes reunidas en Madrid.

\title{
SIGLAS Y REFERENCIAS
}

\author{
AGI Archivo General de Indias, Sevilla, España. \\ AGN Archivo General de la Nación, Ciudad de México, México. \\ $\mathrm{BDH}$ Biblioteca Digital Hispánica. \\ BNAH Biblioteca Nacional de Antropología e Historia, Ciudad \\ de México, México. \\ BNE Biblioteca Nacional de España, Madrid, España. \\ BNM-FR Biblioteca Nacional de México, Fondo Reservado, Ciudad \\ de México, México. \\ BPEJ Biblioteca Pública del Estado de Jalisco “Juan José Arreo- \\ la", Guadalajara, México. \\ CEHM-CARSO Centro de Estudios de Historia de México-CARSO, Ciu- \\ dad de México, México.
}

Alamán, Lucas, Historia de México, México, Imprenta de Victoriano Agüeros, vol. IV, 1885.

Álvarez Cuartero, Izaskun (ed.), Conflicto, negociación y resistencia en las Américas, Salamanca, Universidad de Salamanca, 2017.

Archer, Christon I., "The Royalist Army in New Spain: Civil-Military Relationships, 1810-1821", en Journal of Latin American Studies, XIII: 1 (1981), pp. 65-82.

Artola, Andoni, “La alianza imposible. Los obispos y el Estado (18141833)”, en Investigaciones Históricas. Época Moderna y Contemporánea, 34 (2014), pp. 155-184.

Ávila, Alfredo, "Cuando se canonizó la rebelión. Conservadores y serviles en Nueva España”, en PANi (coord.), 2009, pp. 43-85.

Bergosa y Jordán, Antonio, Nos el Dr. Don..., por la gracia de Dios, Obispo de Antequera de Oaxaca, Arzobispo electo de México, Caballero de la real y distinguida orden de Carlos III del consejo de S. M., México (19 de junio de 1814).

Bergosa y Jordán, Antonio, Nos el Doctor Don..., Caballero de la real y distinguida Orden Española de Carlos III, Obispo de Antequera de Oaxaca, Arzobispo electo, y Gobernador actual de este Arzobispado de México, del Consejo de su Majestad..., México (31 de diciembre de 1814). 
Beristain de Souza, José Mariano, Discurso eucarístico que en la muy solemne acción de gracias celebrada por el Real Consulado de México y el regimiento de su comercio por la libertad y restitución a su trono de Fernando séptimo... pronunció en la iglesia de San Francisco el Grande de México el domingo 13 de noviembre de 1814... el Señor..., México, Oficina de doña María Fernández de Jáuregui, 1814.

BeristáIn de Souza, José Mariano, Discurso cristiano declamatorio contra los rebeldes de la Nueva España, reimpreso en Madrid, Álvarez, 1816 (México, Oficina de José María Benavente).

Bernabéu, Salvador, "El vacío habitado. Jesuitas reales y simulados en México durante los años de la supresión (1767-1816)", en Historia Mexicana, LVIII: 4 (232) (abr.-jun 2009), pp. 1261-1303.

BREÑA, Roberto, El primer liberalismo español y los procesos de emancipación en América, 1808-1824. Una revisión historiográfica del liberalismo bispánico, México, El Colegio de México, 2006.

BreÑa, Roberto (ed.), Cádiz a debate: actualidad, contexto y legado, México, El Colegio de México, 2014.

Butrón, Gonzalo, "Redefinir rey y soberanía: el retorno de Fernando VII y la agonía del liberalismo", en Pasado y Memoria, 13 (2014), pp. 59-78.

CABrera, Miguel Ángel y Juan Pro (eds.), La creación de las culturas políticas modernas, 1808-1833, Madrid y Zaragoza, Marcial Pons y Prensas Universidad de Zaragoza, 2014.

Calvo, Antonio, "La Constitución de la monarquía: absolutismo y pactismo en el reinado de Carlos IV”, en Frasquet y García Monerris (eds.), 2018, pp. 165-192.

Camp, Roderic A., Charles A. Hale, Josefina Zoraida Vázquez (eds.), Los intelectuales y el poder en México, México y Los Ángeles, El Colegio de México y University of California, 1991.

CAmpos, Melchor, "Del absolutismo regio a la monarquía constitucional. Destrucción ritual de soberanos y crisis del estoicismo político en Yucatán (1808-1820)", en SERRANo (coord.), 2014, pp. 107-158.

Cantos, Marieta y Alberto Ramos (eds.), La represión absolutista y el exilio, Cádiz, Universidad de Cádiz, 2015. 
Caron, Jean-Claude y Jean-Philippe Luis, "Le temps des Restaurations", en CARON, y Luis (dirs.), Rien appris, rien oublié? Les Restaurations dans l'Europe postnapoléonienne (1814-1830), Rennes, Presses Universitaires de Rennes, 2015, pp. 461-466.

CARRasco y Enciso, Luis, Sermón encarístico por el venturoso restablecimiento del Tribunal Santo de la Inquisición, y por la fausta agradable restitución de nuestro augusto soberano el señor don Fernando séptimo al trono de las Españas, México, Imprenta de doña María Fernández de Jáuregui, 1815.

Chaparro Silva, Alexander, “«Todas las cosas tienen su tiempo.» Temporalidad e historia durante la restauración monárquica en la Tierra Firme (18141819)", en Anuario Colombiano de Historia Social y Cultural, 45: 2 (2018), pp. 206-231.

Chust, Manuel e Ivana Frasquet, Tiempos de revolución. Comprender las independencias iberoamericanas, Madrid, Taurus, 2013.

Colombini, Francisco María, Invectiva fraternal cristiana a nuestros desgraciados hermanos los rebeldes de la Nueva España, México, Imprenta de doña María Fernández de Jáuregui, 1815.

Compagnon, Antoine, Los antimodernos, Barcelona, Acantilado, 2007.

Connaughton, Brian, “¿Politización de la religión o nueva sacralización de la política? El sermón en las mutaciones públicas de 1808-1824”, en CoNNAUGHTON (ed.), 2010, pp. 160-200.

Connaughton, Brian, Entre la voz de Dios y el llamado de la patria, México, Fondo de Cultura Económica, 2010.

Connaughton, Brian, Ideología y sociedad en Guadalajara (1788-1853): la Iglesia católica y la disputa por definir la nación mexicana, México, Conaculta, 2012.

Connaughton, Brian (ed.), Religión, política e identidad en la independencia de México, México, Universidad Autónoma Metropolitana, 2010.

Díaz Pérez y Calvillo, Juan Bautista, Elogio de San Ignacio de Loyola, fundador de la Compañía de Jesús, predicado en su primera festividad después del restablecimiento de dicha Compañia en esta corte, el 31 de julio de 1816, en la capilla del Real y más antiguo Colegio de San Ildefonso, México, calle de Santo Domingo y esquina de Tacuba, 1816. 
Diego-Fernández, Rafael y María Pilar Gutiérrez, “José de la Cruz en el theatro de la Nueva Galicia (1811-1821)”, en Serrano (coord.), 2014, pp. 229-274.

Diz-Lois, M ${ }^{a}$ Cristina, El manifiesto de 1814, Pamplona, Ediciones Universidad de Navarra, 1967.

EsCrig Rosa, Josep, "Los «príncipes del siglo». Modelos e imaginarios de monarquía antiliberal en tiempos de revolución (1810-1825)", en Alcores. Revista de Historia Contemporánea, 21 (2017), pp. 139-159.

Espíritu Santo, Bernardo del, Carta pastoral del Ilmo. Sr..., México, Imprenta de Juan Bautista de Arizpe, 1818.

FARRIS, Nancy, La corona y el clero en el México colonial, 1579-1821. La crisis del privilegio eclesiástico, México, Fondo de Cultura Económica, 1995 [1968].

Fernández de San Salvador, Agustín Pomposo, Fernando VII en España y por él la religión triunfante y la Europa vengada. Vaticinios poéticos del Dr... premiado el segundo por la Universidad de México en el Certamen literario celebrado el día 29 de octubre de 1809, y casi enteramente cumplidos hoy, México, Oficina de don Mariano Ontiveros, 1814.

Fernández de San Salvador, Agustín Pomposo, El modelo de los cristianos presentado a los insurgentes de América. Y una introducción necesarísima para desengaño de muchos en las actuales circunstancias, en la cual se funda el derecho de la soberanía propia del Sr. D. Fernando VII, y se manifiestan las nulidades y vicios horrendos con que los materialistas introducidos por Napoleón en las Cortes nos iban a sumergir en las llamas de un volcán, semejante a aquel en que los jacobinos sumergieron a la Francia, y del cual nos ha librado la divina providencia con la restitución del amado rey y de su soberanía, quitando todo pretexto a la rebelión, México, Oficina de Ontiveros, 1814.

Fernández de San Salvador, Agustín Pomposo, Los jesuitas quitados y restituidos al mundo. Historia de la antigua California, México, Oficina de don Mariano Ontiveros, 1816.

Frasquet, Ivana, "Restauración y revolución en el Atlántico hispanoamericano”, en Rújula y Ramón Solans (eds.), 2016, pp. 29-49.

Frasquet, Ivana, "En defensa de la Constitución. Persecución y juicio a los diputados de las Cortes en tiempos contrarrevolucionarios, 1814-1815”, en FrasQuet y García Monerris (eds.), 2018, pp. 213-238. 
Frasquet, Ivana y Encarna García Monerris (eds.), Tiempo de política, tiempo de Constitución. La monarquia hispánica entre la revolución y la reacción (1780-1840), Granada, España, Comares, 2018.

García Monerris, Encarna y Carmen García Monerris, La nación secuestrada. Francisco Javier Elío. Correspondencia y manifiesto, Valencia, Publicacions Universitat de València, 2008.

García Monerris, Encarna y Carmen García Monerris, "Palabras en guerra. La experiencia revolucionaria y el lenguaje de la reacción”, en Pasado y Memoria, 10 (2011), pp. 139-162.

García Monerris, Encarna y Carmen García Monerris, Las cosas del rey. Historia política de una desavenencia (1808-1874), Madrid, Akal, 2015.

García Monerris, Encarna y Carmen García Monerris, "El rey depredador”, en Historia Constitucional, 18 (2017), pp. 21-47.

García Monerris, Encarna y Josep Escrig Rosa, “Apologistas y detractores. El primer discurso antiliberal en la historiografía”, en GARCía MONERRIS, Frasquet y García Monerris (eds.), 2016, pp. 31-72.

García Monerris, Encarna, Ivana Frasquet y Carmen García Monerris (eds.), Cuando todo era posible. Liberalismo y antiliberalismo en España e Hispanoamérica, 1780-1842, Madrid, Sílex, 2016.

García Sanz, Fernando, Vittorio Scotti Douglas et al. (coords.), Cadice e oltre: costituzione, nazione e libertà. La carta gaditana nel bicentenario della sua promulgazione, Roma, Istituto per la Storia del Risorgimento Italiano, 2015.

García Torres, José Julio, José Julio García Torres se congratula con sus compatriotas y hermanos los hijos de una y otra España por la feliz restitución a su trono de nuestro adorado y católico monarca el Señor D. Fernando VII, México, Imprenta de don José María Benavente, 1814.

Gómez, Cristina, El obispo Pérez y la revolución de independencia, Puebla, Gobierno del Estado de Puebla, 1991.

Gómez, Cristina, "La iglesia poblana. Del regalismo al ultramontanismo", en SERRANO (coord.), 2014, pp. 55-75.

GonzÁlez, Juan, Sermón histórico-eucarístico, que en la anual y solemne función, que la Real congregación de naturales y originarios del principado de 
Asturias y obispado de Oviedo hace a su singular patrona María Santísima de Covadonga en la iglesia de N. P. Santo Domingo de México, predicó el día 12 de noviembre de 1815..., México, Oficina de don José María de Benavente, 1816.

González de Araujo y SAn Román, Pedro, Impugnación de algunos impios, blasfemos, sacrílegos y sediciosos artículos del código de anarquí..., reimpreso en Madrid, Imprenta Real, 1817 (México, Imprenta de la calle de Santo Domingo, 1816).

Guerra, François-Xavier, Modernidad e independencias. Ensayos sobre las revoluciones hispánicas, México, Fondo de Cultura Económica, 2014 (1992).

Gutiérrez, Daniel y Juan Luis Ossa, “La Restauración como fenómeno extra-europeo, 1814-1826” (presentación de dossier), en Revista Universitaria de Historia Militar, viI: 15 (2018), pp. 10-15.

GuzMán Pérez, Moisés, "Repensar la insurgencia novohispana: precisiones y matices en torno al liberalismo gaditano”, en BREÑA (ed.), 2014, pp. 339-358.

HaLler, Karl-Ludwig von, Restauration der Staats-Wissenschaft oder Theorie des natürlich-geselligen Zustands; der Chimäre des Künstlich-bürgerlichen entgegengesetzt, 6 vols., Winterthur, Steinerishcen Buchhandlung, 1816-1834.

Hamill, Hugh, The Hidalgo Revolt: Prelude to Mexican Independence, Gainesville, University of Florida Press, 1966.

Hamill, Hugh, "The rector to the rescue: royalist pamphleteers in the defense of Mexico, 1808-1821”, en Camp, Hale, Vázquez (eds.), 1991, pp. 49-61.

HamnetT, Brian, “Antonio Bergosa y Jordán (1748-1819), obispo de México. ¿ilustrado?, ¿reaccionario?, ¿contemporizador y oportunista?”, en Historia Mexicana, LIx: 1 (233) (jul.-sep. 2009), pp. 117-136.

Hamnett, Brian, Raíces de la insurgencia en México. Historia regional, 17501824, México, Fondo de Cultura Económica, 2010 [1986].

Hamnett, Brian, Revolución y contrarrevolución en México y el Perú. Liberales, realistas y separatistas, 1800-1824, México, Fondo de Cultura Económica, 2011 [1976].

Herrejón, Carlos, Los procesos de Morelos, Zamora, Mich., El Colegio de Michoacán, 1985. 
Herrejón, Carlos, Del sermón al discurso cívico: México, 1760-1834, Zamora, México, El Colegio de Michoacán y El Colegio de México, 2003.

Herrejón, Carlos, Morelos, Zamora, Mich., El Colegio de Michoacán, 2016.

Herrero, Javier, Los orígenes del pensamiento reaccionario español, Madrid, Alianza, 1988 [1971].

IBARRA, Ana Carolina, “ «La justicia de la causa insurgente»: razón y retórica del clero insurgente de la Nueva España”, en Anuario de Historia de la Iglesia, 17 (2008), pp. 63-80.

Ibarra, Ana Carolina, "Cambios en la percepción y el sentido de la historia (Nueva España, 1816-1820)”, en Historia Mexicana, LXIII: 2 (250) (oct.-dic. 2013), pp. 645-688.

Ibarra, Ana Carolina, La insurgencia mexicana y la constitución de Apatzingán 1805-1824, México, Universidad Nacional Autónoma de México, 2014.

Ibarra López, Daniela, “Diezmos y guerra en el obispado de Michoacán (1815-1821)”, en SERrano (coord.), 2014, pp. 46-51.

Kissinger, Henry A., Un mundo restaurado, México, Fondo de Cultura Económica, 1973 [1964].

Koselleck, Reinhardt, Futuro pasado. Para una semántica de los tiempos bistóricos, Barcelona, España, Paidós, 1993.

La Parra, Emilio, "Fernando VII, el rey providencial enviado de Dios", en Alcores. Revista de Historia Contemporánea, 17 (2014), pp. 39-53.

La Parra, Emilio, "La restauración de Fernando VII en 1814", en Historia Constitucional, 15 (2014), pp. 205-222.

La Parra, Emilio, Fernando VII. Un rey deseado y detestado, Barcelona, España, Tusquets, 2018.

La Parra, Emilio y $\mathrm{M}^{\mathrm{a}}$ Ángeles Casado, La Inquisición en España. Agonía y abolición, Madrid, Catarata, 2013.

Landavazo, Marco Antonio, La máscara de Fernando VII. Discurso e imaginario monárquico en una época de crisis. Nueva España, 1808-1821, México, 
El Colegio de México, Zamora, Michoacán, El Colegio de Michoacán, Universidad Michoacana de San Nicolás de Hidalgo, 2001.

LeRdo DE Tejada, Ignacio, Discurso que en la profesión solemne de cuarto voto hecha por los RR. PP. de la Compañia de Jesús José María Castañiza y Pedro Cantón en el día quince de agosto de este año, y en la primera misa pontifical que celebraba el Ilmo. Sr. Dr. D. Juan Francisco de Castañiza... pronunció..., México, Calle de Santo Domingo y esquina de Tacuba, 1816.

López Alós, Javier, Entre el trono y el escaño. El pensamiento reaccionario español frente a la Revolución Liberal, Madrid, Congreso de los Diputados, 2011.

Luengo, Manuel, Diario de 1814 y 1815. El final del destierro y la restauración de la Compañia de Jesús, edición de Inmaculada Fernández y Carlos Martínez, Alicante, Publicaciones de la Universidad de Alicante y Universidad Pontifícia Comillas, 2015.

LuIs, Jean-Philippe, "La construcción inacabada de una cultura política realista”, en Cabrera y Pro (eds.), 2014, pp. 319-346.

MejíA, Eugenio, "La transición a un gobierno republicano. La Junta Subalterna de la insurgencia (1815-1820)", en SERRANo (coord.), 2014, pp. 331-374.

Moliner Prada, Antonio, "El antiliberalismo eclesiástico en la primera Restauración absolutista (1814-1820)”, en Hispania Nova, 3 (2003), pp. 51-72.

Moreno, Rodrigo, “Los realistas: historiografía, semántica y milicia”, en Historia Mexicana, Lxvi: 3 (263) (ene.-mar. 2017), pp. 1077-1122.

Moreno, Rodrigo, "La Restauración en la Nueva España: guerra, cambios de régimen y militarización entre 1814 y 1820", en Revista Universitaria de Historia Militar, viI: 15 (2018), pp. 101-125.

Moreno y Bazo, Jacinto, Sermón de acción de gracias a Dios nuestro señor por la restauración feliz de nuestro amado soberano el Señor don Fernando VII a su trono. Predicado el día 8 de mayo de 1815 en la santa Iglesia catedral de Antequera de Oaxaca por el Dr...., Nueva Guatemala, 1815.

Murillo Ferrol, Francisco, "El «Manifiesto de los Persas» y los orígenes del liberalismo español”, en Homenaje a D. Nicolás Pérez Serrano, Madrid, Instituto Editorial Reus, 1959, t. II, pp. 164-165. 
Olveda, Jaime, Los discursos opuestos sobre la independencia de la Nueva España, Madrid, Doce Calles, 2006.

Olveda, Jaime, "Cádiz y Apatzingán. Dos constituciones en pugna”, en IbARRA (coord.), 2014, La insurgencia mexicana y la Constitución de Apatzingán, México, Universidad Nacional Autónoma de México, 2014, pp. 121-133.

O'Phelan, Scarlett, "Abascal y el fantasma de las conspiraciones", en O’Phelan y Lomné (eds.), 2013, pp. 121-146.

O'Phelan, Scarlett y Georges Lomné (eds.), Abascal y la contra-independencia de América del Sur, Lima, Institut Français d'Études Ándines, Pontificia Universidad Católica del Perú, 2013.

OrRuño, José María, ¿Para qué sirven los frailes en el mundo? Sermón panegírico que el día 25 de septiembre de 1814..., México, Oficina de don José María Benavente, 1815.

OrTiz, Juan, Guerra y gobierno. Los pueblos y la independencia de México, 1808-1825, México, El Colegio de México e Instituto de Investigaciones Dr. José María Luis Mora, 2014.

Ortiz, Juan, Calleja. Guerra, botin y fortuna, México, Universidad Veracruzana y El Colegio de Michoacán, 2017.

Pani, Erika (coord.), Conservadurismo y derechas en la historia de México, México, Fondo de Cultura Económica, 2009, t. I.

Pérez, Antonio Joaquín, Pastoral del obispo de la Puebla de los Ángeles a sus diocesanos, Madrid, por don Francisco Martínez Dávila, 1815.

Pérez Memen, Fernando, El episcopado y la independencia de México (18101836), México, El Colegio de México, 2011 [1972].

Pérez Vejo, Tomás, “Una Restauración que no restaura: América y el camino de la independencia”, en Jerónimo Zurita. Revista de historia, 91 (2016), pp. 163-182.

QueZADA, José Luis, ¿Una Inquisición constitucional? El tribunal protector de la fe del arzobispo de México, 1813-1814, Zamora, El Colegio de Michoacán, 2016. 
Ramírez, Susana María, "Las «Actas de Fidelidad» de 1815 en la Nueva España: una tipología documental a favor de Fernando VII”, en Álvarez Cuartero (ed.), 2017, pp. 215-240.

Representación y Manifiesto que algunos diputados de las Cortes ordinarias firmaron en los mayores apuros de su opresión en Madrid, para que la majestad del señor D. Fernando VII a la entrada en España de vuelta de su cautividad, se penetrase del estado de la nación, del deseo de sus provincias, y del remedio que creian oportuno; todo fue presentado a S. M. en Valencia por uno de dichos diputados, y se imprime en cumplimiento de Real Orden, Cádiz, Oficina de don Nicolás, 1814.

Revuelta, Manuel, El restablecimiento de la Compañia de Jesús. Celebración del bicentenario, Bilbao, España, Mensajero, 2013.

Rivera, Antonio, Reacción y revolución en la España liberal, Madrid, Biblioteca Nueva, 2006.

RocA, Jordi, "La Restauración de Fernando VII: la transformación represiva y autoritaria de la monarquía. Barcelona, de Manuel Casamada a Luis Lacy", en Rúbrica Contemporánea, 8 (2015), pp. 5-28.

Rodríguez López-Brea, Carlos, “¿Alianza entre trono y altar? La Iglesia y la política fiscal de Fernando VII en la diócesis de Toledo (1814-1820)", en Spagna contemporanea, 19 (2001), pp. 29-46.

Rodríguez Tapia, Andrea, "Los opositores al movimiento de Miguel Hidalgo. Representaciones e interpretaciones historiográficas, 1810-1852", tesis de licenciatura en historia, México, Universidad Nacional Autónoma de México, 2010.

Rosas, Sergio, "El Cabildo Catedral de Puebla durante el sexenio absolutista: entre la lealtad monárquica y la división popular", en Fronteras de la historia, 21: 2 (2016), pp. 156-182.

Rújula, Pedro, "Recomponer el mundo después de Napoleón: 1814 y las Restauraciones", en Pasado y Memoria, 13 (2014), pp. 11-15 (presentación al dossier).

Rújula, Pedro, "El mito contrarrevolucionario de la «Restauración»", en Pasado y Memoria, 13 (2014), pp. 79-97.

Rújula, Pedro, "Reacción en las Cortes de Cádiz: Los orígenes parlamentarios del golpe de mayo de 1814", en García SANZ, ScotTi Douglas et al. (coords.), 2015, pp. 257-278. 
Rújula, Pedro y Javier Ramón Solans (eds.), El desafío de la revolución. Reaccionarios, antiliberales y contrarrevolucionarios (siglos XVIII y XIX), Granada, España, Comares, 2016.

Salvador, Josef del, Sermón de la primera dominica de adviento predicado al rey nuestro señor en su Real capilla el día 27 de noviembre de este año de 1814 por..., México, reimpreso en la imprenta de doña María Fernández de Jáuregui, 1815.

San Bartolomé, José de, El duelo de la Inquisición o pésame que un filósofo rancio da a sus amados compatriotas los verdaderos españoles por la extinción de tan santo y utilísimo Tribunal, México, Oficina de doña María Fernández de Jáuregui, 1814.

SAN BARTOLOMÉ, José de, El liberalismo y la rebelión confundidas por una tierna y delicada doncella, México, Oficina de la calle de Santo Domingo y esquina de Tacuba, 1817.

Saucedo, Carmen, "La Convención de las Provincias Orientales. Un proyecto de gobierno insurgente", en SERRANo (coord.), 2014, pp. 375-396.

Serrano, José Antonio, "El discurso de la unión: el patriotismo novohispano en la propaganda realista durante el movimiento insurgente de Hidalgo", en Estudios de Historia Novohispana, 14 (1994), pp. 157-177.

SERRANO, José Antonio, Jerarquía territorial y transición política. Guanajuato, 1790-1836, México, El Colegio de Michoacán, Instituto de Investigaciones Dr. José María Luis Mora, 2001.

Serrano, José Antonio, “Las herencias ilustradas y gaditanas en tiempos del absolutismo. Nueva España (1814-1819)”, en SERrano (coord.), 2014, pp. 191-227.

Serrano, José Antonio (coord.), El sexenio absolutista. Los últimos años insurgentes. Nueva España (1814-1820), Zamora, Mich., El Colegio de Michoacán, 2014.

SuÁrez Verdeguer, Federico, Conservadores, innovadores y renovadores en las postrimerías del Antigno Régimen, Pamplona, Publicaciones del Estudio General de Navarra, 1955.

Terán, Marta, "La Virgen de Guadalupe contra Napoleón Bonaparte. La defensa de la religión en el obispado de Michoacán entre 1793-1814”, en Estudios de Historia Novohispana, 19 (1999), pp. 92-129. 
Toral, Manuel, Pronóstico funesto de inmensos males en que pretenden anegar a la América las impias máximas de la rebelión, México, Alejandro Valdés, 1818.

Torre Villar, Ernesto de la, La independencia de México, México, Fondo de Cultura Económica, 2010 [1992].

Torres Puga, Gabriel, "El último aliento de la Inquisición de México (18151820)”, en Serrano (coord.), 2014, pp. 77-105.

VAsconcelos, Ignacio Mariano, Sermón predicado el día 8 de mayo de 1815 por... en la solemne función de gracias que hizo la N. C. de Oaxaca por la libertad del Santísimo Padre Sumo Pontífice Pio VII, México, Imprenta de la calle de Santo Domingo y esquina de Tacuba, 1816.

VÉLEz, Rafael de, Apología del altar y del trono, o Historia de las reformas hechas en España en tiempo de las llamadas Cortes, e impugnación de algunas doctrinas publicadas en la Constitución, diarios, y otros escritos contra la religión y el Estado, t. II, Madrid, Imprenta de Cano, 1818, México, Alejandro Valdés, 1822.

ZaPaTA, José María, Sermón moral que para concluir el novenario celebrado en esta santa iglesia catedral de la Puebla de los Ángeles, a petición de su muy ilustre Ayuntamiento... implorando la felicidad de nuestro soberano el Sr. D. Fernando séptimo (Q. D. G.) libre del cautiverio de Francia, y regresado al seno de su España, las lluvias que tanto se escasean con daño del público; y el buen éxito de las armas católicas en las presentes guerras, predicó el día 1 de junio de 1814 el Doctor..., Puebla, Oficina de don Pedro de la Rosa, 1814.

ZaYAS de Lille, Gabriela, "Los sermones políticos de José Mariano Beristáin de Souza”, en Nueva Revista de Filología Hispánica, XL: 2 (1992), pp. 719-759.

Zermeño, Guillermo, "El retorno de los jesuitas a México en el siglo xix: algunas paradojas", en Historia Mexicana, LxIv: 4(256) (abr.-jun. 2015), pp. 1463-1540. 